\title{
Abnormal Phrenic Motoneuron Activity and Morphology in Neonatal Monoamine Oxidase A-Deficient Transgenic Mice: Possible Role of a Serotonin Excess
}

\author{
Céline Bou-Flores, ${ }^{1}$ Anne-Marie Lajard, ${ }^{2}$ Roger Monteau, ${ }^{2}$ Edward De Maeyer, ${ }^{4}$ Isabelle Seif, ${ }^{4}$ Jeanne Lanoir, ${ }^{3}$ \\ and Gérard Hilaire ${ }^{1}$ \\ 1 Unité Propre de Recherche (UPR) 9011, Development and Pathology of Movement, 2Unité Propre de Recherche et de \\ I'Enseignement Supérieur 6034, Laboratoire Neurobiologie des Fonctions Végétatives, and 3UPR 9024, Laboratoire de \\ Neurobiologie, Centre National de la Recherche Scientifique (CNRS), Marseille Cedex 20, France, and 4 Unité Mixte de \\ Recherche 146, CNRS, Institut Curie, 91405 Orsay, France
}

In rodent neonates, the neurotransmitter serotonin (5- HT) modulates the activity of both the medullary respiratory rhythm generator and the cervical phrenic motoneurons. To determine whether 5-HT also contributes to the maturation of the respiratory network, experiments were conducted in vitro on the brainstem-spinal cord preparation of neonatal mice originating from the control strain $(\mathrm{C} 3 \mathrm{H})$ and the monoamine oxidase A-deficient strain, which has a brain perinatal 5-HT excess (Tg8). At birth, the Tg8 respiratory network is unable to generate a respiratory pattern as stable as that produced by the $\mathrm{C} 3 \mathrm{H}$ network, and the modulation by 5-HT of the network activity present in $\mathrm{C} 3 \mathrm{H}$ neonates is lacking in Tg8 neonates. In addition, the morphology of the phrenic motoneurons is altered in Tg8 neonates; the motoneuron dendritic tree loses the $\mathrm{C} 3 \mathrm{H}$ bipolar aspect but exhibits an increased number of spines and varicosities. These abnormalities were prevented in Tg8 neonates by treating pregnant Tg8 dams with the 5-HT synthesis inhibitor $p$-chlorophenylalanine or a $5-\mathrm{HT}_{2 \mathrm{~A}}$ receptor antagonist but were induced in wild-type neonates by treating $\mathrm{C} 3 \mathrm{H}$ dams with a $5-\mathrm{HT}_{2 \mathrm{~A}}$ receptor agonist. We conclude that $5-\mathrm{HT}$ contributes, probably via $5-\mathrm{HT}_{2 \mathrm{~A}}$ receptors, to the normal maturation of the respiratory network but alters it when present in excess. Disorders affecting 5-HT metabolism during gestation may therefore have deleterious effects on newborns.

Key words: serotonin; serotonergic receptors; medullary respiratory network; electrophysiology of phrenic motoneurons; morphology of phrenic motoneurons; fetal mice; neonatal mice; maturation; modulation of neonatal respiratory activity
The respiratory network comprises a medullary network responsible for setting up the rhythmic drive (Bianchi et al., 1995; Koshiya and Smith, 1999) and several pools of motoneurons located in the medulla and the spinal cord (Monteau and Hilaire, 1991; Hilaire and Monteau, 1997). This network is able to produce rhythmic activity in phrenic motoneurons (PhMns) in vitro by embryonic day 15 (E15) in rats, i.e., 1 week before birth (Hilaire and Duron, 1999), although the rhythm and amplitude of this activity are very variable at this age (Di Pasquale et al., 1992). At E18, endogenous serotonin (5-HT) is indispensable to rhythmogenesis because blocking medullary $5-\mathrm{HT}_{1 \mathrm{~A}}$ receptors (5$\mathrm{HT}_{1 \mathrm{~A}} \mathrm{R}$ ) induces respiratory arrests, whereas activating them increases the respiratory frequency (Di Pasquale et al., 1994a). E18-E20 is a critical period in network maturation; respiratory bursting pacemaker neurons begin to fire in the medullary network, the respiratory rhythm and amplitude stabilize, and 5-HT is no longer required (Di Pasquale et al., 1994b, 1996). At birth, 5-HT exerts complex effects, including facilitatory effects on the

\footnotetext{
Received Jan. 10, 2000; revised March 15, 2000; accepted March 27, 2000.

This research was supported by the Centre National de la Recherche Scientifique and the Institut Fédératif de Recherche des Sciences du Cerveau. C.B.-F. was the recipient of a three year fellowship from the Ministère de l'Enseignement, Recherche et Technologies while working on this project. We acknowledge the excellent contribution of Annie Christolomme to binding analysis, Marie Gardette to the figures, and Dr. Jessica Blanc for English revision.

Correspondence should be addressed to Gérard Hilaire, Centre National de la Recherche Scientifique, Unité Propre de Recherche 9011, Laboratoire Neurobiologie et Mouvement, 31 chemin Joseph-Aiguier, 13402 Marseille Cedex 20, France. E-mail: hilaire@dpm.cnrs-mrs.fr.

Copyright (C) 2000 Society for Neuroscience $0270-6474 / 00 / 204646-11 \$ 15.00 / 0$
}

rhythm generator via medullary $5-\mathrm{HT}_{1 \mathrm{~A}} \mathrm{R}$, the recruitment of PhMns via $5-\mathrm{HT}_{2 \mathrm{~A}} \mathrm{R}$ located on their somatic membrane, and inhibitory effects on the transmission of the central drive to PhMns via presynaptic 5-HT ${ }_{1 \mathrm{~B}} \mathrm{R}$ (Morin et al., 1991a,b; Lindsay and Feldman, 1993; Di Pasquale et al., 1994a, 1997; Monteau et al., 1994; Hilaire et al., 1997b).

5-HT is a widely distributed neurotransmitter that is expressed from an early embryonic age and is involved in several nervous maturational processes and functions (Lauder and Krebs, 1978; Vogt, 1982; Lauder et al., 1985; Whitaker-Azmitia, 1991; Hamon and Gozlan, 1993; Lauder, 1993; Hoyer et al., 1994; Peroutka, 1994; Levitt et al., 1997). To determine whether 5-HT affects the maturation of the respiratory network, we compared the respiratory activity at birth between two strains of mice that have different perinatal endogenous 5-HT levels, the wild $\mathrm{C} 3 \mathrm{H} / \mathrm{HeJ}$ strain $(\mathrm{C} 3 \mathrm{H})$ and the transgenic Tg8 strain. The latter was obtained from $\mathrm{C} 3 \mathrm{H}$ (Cases et al., 1995) by performing insertional inactivation on the gene encoding monoamine oxidase A (MAOA), the main enzyme that degrades 5-HT. MAOA deficiency results in brain 5-HT levels that are several times greater than in normal C3H mice (Lajard et al., 1999).

In both strains, we measured the 5-HT levels at E18 and analyzed the in vitro respiratory activity between E20 and postnatal day 5 (P5), the responses to exogenous 5-HT, the electrophysiological properties and dendritic features of PhMns at P0$\mathrm{P} 3$, and the expression of $5-\mathrm{HT}_{1 \mathrm{~A}} \mathrm{R}$ at P7. Several Tg8 anomalies were observed, including failure to develop a stable respiratory rhythm, lack of respiratory response to $5-\mathrm{HT}_{1 \mathrm{~A}} \mathrm{R}$ activation, and 
an abnormal morphology of PhMn dendrites. Because these abnormalities were prevented by prenatal pharmacological treatments affecting the 5-HT system, they probably originated from maturational disturbances attributable to excess 5-HT, which suggests that 5 -HT is actually involved in the maturation of the respiratory network.

\section{MATERIALS AND METHODS}

HPLC experiments. HPLC measurements of 5-HT levels were performed on the brainstem and cervical cord of exteriorized fetuses dissected out from pentobarbitone-anesthetized $(60 \mathrm{mg} / \mathrm{kg})$ timed-pregnant $\mathrm{C} 3 \mathrm{H}$ and Tg8 mice on gestational day 18 (Lajard et al., 1999). Results are expressed as picograms per milligram of tissue.

Electrophysiological experiments. Experiments were performed in vitro on the en bloc medulla-spinal cord preparation of anesthetized fetal and neonatal C3H and Tg8 mice (Di Pasquale et al., 1992; Hilaire et al., 1997a,b). Briefly, the medulla and spinal cord were isolated and superfused with artificial CSF (aCSF) gassed with $95 \% \mathrm{O}_{2}$ plus $5 \% \mathrm{CO}_{2}$ and maintained at $26.5 \pm 1{ }^{\circ} \mathrm{C}$. The activity of the $\mathrm{C} 4$ phrenic roots was recorded with suction electrodes and integrated. To estimate the variability of the phrenic activity, the cycle duration and the amplitude of integrated phrenic bursts were measured during 60 successive cycles, and coefficients of variability $(\mathrm{CVd})$ were defined as the $\mathrm{SD} /$ mean ratio.

Whole-cell recordings were performed using an Axoclamp 2A amplifier (Axon Instruments, Foster City, CA) and 6-8 $\mathrm{M} \Omega$ patch microelectrodes (Di Pasquale et al., 1996). The neurons selected had a 3-5 G $\Omega$ seal, a stable resting membrane potential, and a serial resistance of $<30$ $\mathrm{M} \Omega$. The following parameters were measured between phrenic bursts: (1) the resting potential, (2) the spike amplitude and duration at half amplitude, (3) the membrane input resistance (from voltage changes elicited by a stepped $1 \mathrm{sec}$ negative pulses), (4) the firing threshold (the absolute membrane potential at the onset of the first action potential elicited by a $1 \mathrm{sec}$ depolarizing pulse), and (5) the slope of the $I-F$ relationship when $1 \mathrm{sec}$ depolarizing pulses with a stepped intensity $I$ induce a train of spikes at the frequency $F$.

Analysis of phrenic motoneuron morphology. PhMns were recorded with pipettes containing biocytin for at least $1 \mathrm{hr}$ (resting potential clamped at $-70 \mathrm{mV}$ ). The cervical cord was fixed with $4 \%$ paraformaldehyde in $0.1 \mathrm{~m}$ sodium phosphate buffer, $\mathrm{pH} 7.4$ (48 hr). Frontal sections $(150 \mu \mathrm{m})$ were obtained on a vibroslicer (Campden Instruments, Loughborough, UK) and collected in chilled $0.1 \mathrm{~m}$ sodium PBS (NaPBS) $\mathrm{pH}$ 7.4. Sections were rinsed in NaPBS, treated with Triton X-100 (1\% in NaPBS; Sigma, St. Louis, MO), and incubated in avidin-biotin-HRP complex (ABC Elite kit; Vector Laboratories, Burlingame, CA). After several rinses, they were reacted with diaminobenzidine (DAB kit; Vector Laboratories). The sections were mounted onto gelatin-coated slides, dehydrated (100\% ethanol), cleared (xylene), and coverslipped with DePex. Neurons were observed under a Zeiss (Oberkochen, Germany) microscope (Axiophot) and drawn under a camera lucida. Each PhMn generally appeared on one to two successive slices in the case of $\mathrm{C} 3 \mathrm{H}$ and often on three slices in that of Tg8. Drawings were analyzed with NIH Image software to define the area of the soma, the number, and length of the dendrites of various orders, and the total extent of the dendritic tree. Dendritic spines (thin dendrites $<5 \mu \mathrm{m}$ in length) and swollen varicosities were counted under a Zeiss microscope.

Pharmacological experiments. As described previously (Monteau et al., 1994; Hilaire et al., 1997b), the following drugs [Sigma and Research Biochemicals (Natick, MA)] were diluted in aCSF and applied to the preparations for 4 (5-HT and 5-HTR agonists), 10 (antagonists), and 20 [L-tryptophan (L-Trp)] min: 5-HT and 8-hydroxy-2-(di-n-propyl-amino) tetralin (8-OH-DPAT) as 5- $\mathrm{HT}_{1 \mathrm{~A}} \mathrm{R}$ agonists; methoxyphenyl)-4-[4(2-phthalimido)butyl] piperazine hydrobromide (NAN190) and 4-iodo$N$-[2-[4-(methoxyphenyl)-1-piperazinyl]ethyl]- $N$-2-pyridinyl-benzamide hydrochloride (p-MPPI) as 5- $\mathrm{HT}_{1 \mathrm{~A}} \mathrm{R}$ antagonists; 5-methoxy 3(1,2,3,6tetrahydro 4-pyridinyl) 1-H-indol-succinate (RU24969 from Hoechst Marion Roussel, Frankfurt am Main, Germany) as $5-\mathrm{HT}_{1 \mathrm{~B}} \mathrm{R}$ agonist; $S(-)$-1-(1H-indol-4-yloxy)-3-[(1-methylethy)amino]-2-propanol[(-) pindolol] as 5- $\mathrm{HT}_{1 \mathrm{~B}} \mathrm{R}$ antagonist; 2,5-dimethoxy-4-iodoamphetamine hydrochloride (DOI) and $\alpha \mathrm{CH} 3-5-\mathrm{HT}$ as $5-\mathrm{HT}_{2 \mathrm{~A}} \mathrm{R}$ agonists; and trans,4([3Z)3-(2-dimethylaminoethyl) oxyimino-3(2-fluorophenyl)propen1-yl] phenol hemifumarate\} (SR46349B from Sanofi-Recherche, Montpellier, France) as $5-\mathrm{HT}_{2 \mathrm{~A}} \mathrm{R}$ antagonist. In some experiments, the recording chamber was divided by placing a barrier at the level of the first cervical root, so as to be able to apply drugs to either the medulla or the spinal cord. The control phrenic burst frequency was measured for at least 5 min before any drug application; the frequency under aCSF-containing drug was expressed as a percentage of the control value $(100 \%)$.

To test the effects of short-term treatment on PhMn morphology, 5-HT $(200 \mu \mathrm{M})$ and SR46349B $(80 \mu \mathrm{M})$ were added to aCSF. The aCSFcontaining drug (either 5-HT alone or 5-HT plus SR46349B) was applied instead of normal aCSF while a given PhMn was being recorded with a pipette containing biocytin. To test the effects of long-term treatment, SR46349B and DOI were injected subcutaneously $(0.3 \mathrm{ml})$ to timedpregnant mice $(50 \mathrm{mg} / \mathrm{kg}$ per $24 \mathrm{hr}$ ) from E18 to delivery; sham experiments were performed with $0.3 \mathrm{ml}$ of saline $(n=2)$. The 5 -HT synthesis inhibitor $p$-chlorophenylalanine (PCPA) (Research Biochemicals) was injected into $\mathrm{Tg} 8(n=3)$ and $\mathrm{C} 3 \mathrm{H}(n=2)$ pregnant mice $(300 \mathrm{mg} / \mathrm{kg}$ per $24 \mathrm{hr}$ ) from E18 to delivery and into Tg8 neonates from birth up to and including $\mathrm{P} 2(n=3)$.

Statistics. Results were expressed as the mean \pm SEM in all the experiments, except for those on the PhMn morphology, which were expressed as the median \pm quartile deviation to avoid having to make any assumptions about the normality of the distribution. Pharmacological experiments were repeated on several preparations to evaluate any differences existing between control aCSF and drug-containing aCSF, which were taken to be significant at $p<0.05$ (paired $t$ test). In biochemical and electrophysiological experiments, differences between the mean $\mathrm{C} 3 \mathrm{H}$ and $\mathrm{Tg} 8$ values were taken to be significant at $p<0.05$ (unpaired $t$ test). Regarding the PhMn morphology, the working hypothesis that $\mathrm{C} 3 \mathrm{H}$ and $\mathrm{Tg} 8 \mathrm{PhMns}$ were different was tested by comparing the data (significance level of $p<0.05$ ) by performing nonparametric tests, i.e., the Mann-Whitney $U$ test for two independent groups. The working hypothesis that the pharmacological treatments affected the PhMn morphology was evaluated $(p<0.05)$ by performing an ANOVA-1 test on ranks on the three groups $(\mathrm{C} 3 \mathrm{H}, \mathrm{Tg} 8$, and a treated group), i.e., the Kruskal-Wallis test followed by Dunnett's test (SigmaStat Software).

Autoradiographic experiments. $5-\mathrm{HT}_{1 \mathrm{~A}} \mathrm{R}$ binding experiments were performed on cryostat-prepared, $25-\mu \mathrm{m}$-thick brainstem and cervical cord sections (Boulenguez et al., 1991) from four sets of 7-d-old C3H and $\mathrm{Tg} 8$ neonates. Three sets consisted of one $\mathrm{C} 3 \mathrm{H}$ and one $\mathrm{Tg} 8$ pup, and the fourth set comprised two $\mathrm{C} 3 \mathrm{H}$ neonates from the same litter and one $\mathrm{Tg} 8$ neonate. The brain tissue from each set was processed and analyzed simultaneously throughout the experiment, from freezing to quantitative autoradiography. Serial frontal sections were collected on gelatin-coated slides, which were stored at $-80^{\circ} \mathrm{C}$ before being incubated in a specific 5- $\mathrm{HT}_{1 \mathrm{~A}} \mathrm{R}$ radioligand, $\left[{ }^{3} \mathrm{H}\right] 8-\mathrm{OH}-\mathrm{DPAT}$ (specific activity, $127 \mathrm{Ci} / \mathrm{mmol}$, $2 \mathrm{~nm}$ in Krebs' medium, at $25^{\circ} \mathrm{C}$ for $1 \mathrm{hr}$; NEN, Boston, MA). After quick washing and drying, sections from similar regions of both strains were exposed on the same sheet of film for $2.5-3$ months $\left(\left[{ }^{3} \mathrm{H}\right] \mathrm{Hyperfilm}\right.$; Amersham Pharmacia Biotech, Arlington Heights, IL). Quantitative analysis of the autoradiograms was performed with a computer image analysis device [PowerMacIntosh (Apple Computers, Cupertino, CA) and the Biolab software program]. Histograms were drawn, and statistical analysis (unpaired $t$ test) was performed using the Prism 2.0 software program (GraphPad, San Diego, CA). The mean value of the specific binding recorded in each structure was expressed in femtomoles per milligram of tissue ( $\pm \mathrm{SEM})$, based on $n$ sections analyzed from three to five individuals of each strain.

\section{RESULTS \\ Very high 5-HT concentrations occur in Tg8 fetuses at $\mathrm{E} 18$}

The 5-HT levels are only 4- and 1.5-fold higher than normal in brainstem and cervical cord from Tg8 fetuses at E20, whereas they are 8- and 3.5-fold higher in Tg8 neonates at P5 (Lajard et al., 1999). The increase in endogenous 5-HT levels in Tg8 mice from E20 to P5 raises the question of 5-HT levels at E18 because a major step in respiratory network maturation occurs between E18 and E20. We therefore measured the 5-HT levels in E18 fetuses of $\mathrm{C} 3 \mathrm{H}$ and $\mathrm{Tg} 8$ mice. They were 4.8 -fold higher than normal in Tg8 brainstem (986 \pm 92 vs $204 \pm 85 \mathrm{pg} / \mathrm{mg}$, mean \pm SEM, $n=4)$ and 6.3-fold higher in Tg8 cervical cord (729 \pm 203 vs $115 \pm 95 \mathrm{pg} / \mathrm{mg}$ ). During maturation from E18 to P5, Tg8 PhMns and medullary neurons are actually exposed to very high 5-HT levels. 

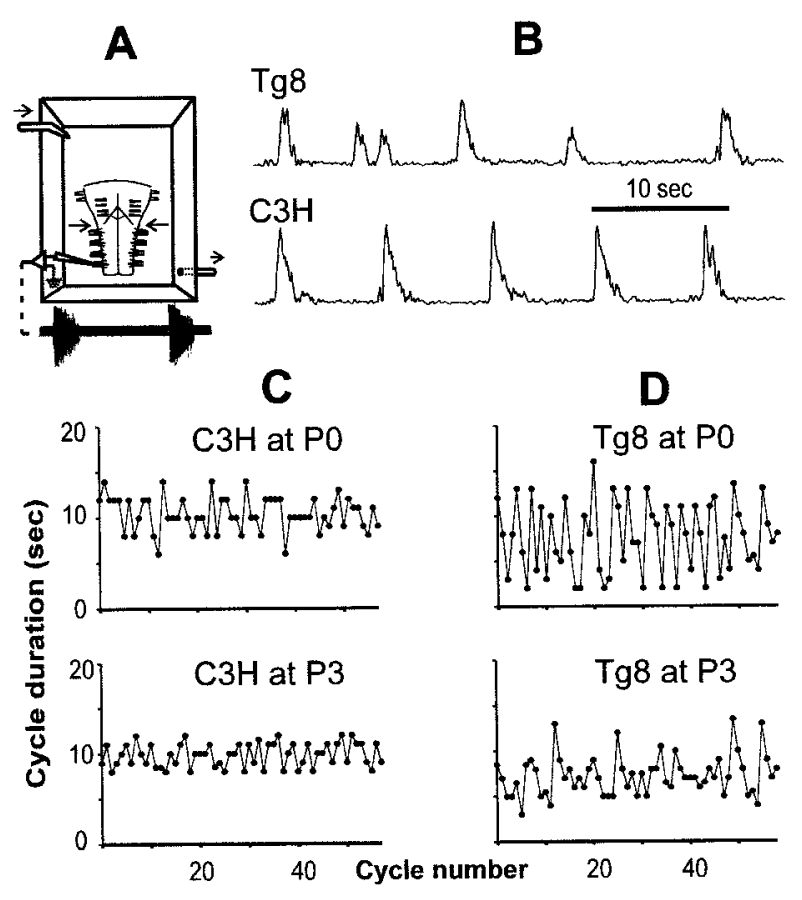

E

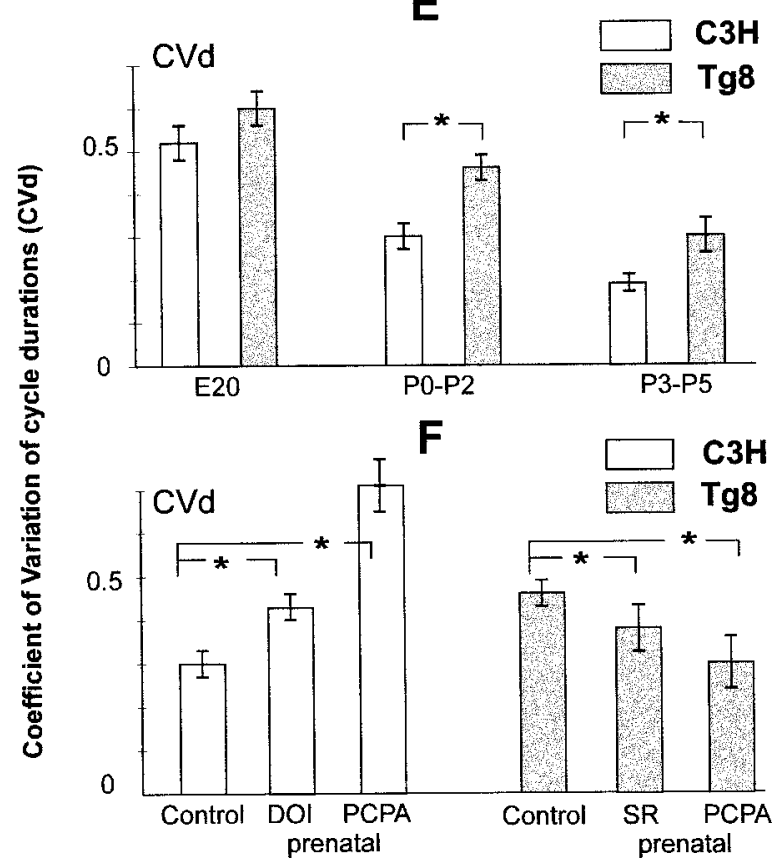

Figure 1. The in vitro phrenic activity is more variable in $\operatorname{Tg} 8$ than in $\mathrm{C} 3 \mathrm{H}$ neonatal preparations. $A$, Drawing of the medulla-cervical cord preparation in which the respiratory network continues to produce rhythmic phrenic nerve discharges (Hilaire et al., 1997a). $B$, The amplitude and cycle duration of the integrated phrenic bursts are both stable in $\mathrm{C} 3 \mathrm{H}$ but variable in $\mathrm{Tg} 8$ preparations. $C$, Histograms showing the cycle duration variations in $\mathrm{C} 3 \mathrm{H}$ neonates aged $\mathrm{P} 0(\mathrm{C} 3 \mathrm{H}$ at $\mathrm{PO})$ and $\mathrm{P} 3(\mathrm{C} 3 \mathrm{H}$ at $\mathrm{P} 3)$ during 60 successive cycles: $\mathrm{CVd}(\mathrm{SD} /$ mean ratio) of 0.21 for the $\mathrm{P} 0$ histogram and 0.15 for the $\mathrm{P} 3$ histogram. $D$, Greater variability of cycle durations in $\mathrm{Tg} 8$ neonates: $\mathrm{CVd}$ of 0.52 at $\mathrm{P} 0$ and 0.29 at P3. E, Cycle duration variability, as expressed by mean $\mathrm{CVd}$, decreases with age from E20 to P3-P5 in both strains but is significantly greater in $\mathrm{Tg} 8$ during postnatal life $\left({ }^{*} p<0.05\right)$. At E20, $n=5$ and 4 for $\mathrm{C} 3 \mathrm{H}$ and $\mathrm{Tg} 8$ fetuses, respectively; at $\mathrm{P} 0-\mathrm{P} 2, n=18$ and 21 for $\mathrm{C} 3 \mathrm{H}$ and $\mathrm{Tg} 8$ neonates, respectively; at $\mathrm{P} 3-\mathrm{P} 5, n=11$ and 9 for $\mathrm{C} 3 \mathrm{H}$ and $\mathrm{Tg} 8$ neonates, respectively. $F$, Pharmacology of $\mathrm{CVd}$ on $\mathrm{P} 0-\mathrm{P} 2$ neonates. Mean $\mathrm{CVd}$ is significantly greater in both $\mathrm{C} 3 \mathrm{H}$ neonates $(n=5)$ born from dams treated
Greater variability of phrenic burst cycle durations and integrated phrenic burst amplitudes in Tg8 neonatal preparations

In both $\mathrm{C} 3 \mathrm{H}$ and $\mathrm{Tg} 8$ medulla-cervical cord preparations (Fig. $1 A$ ), the isolated respiratory centers produced phrenic bursts at similar frequency between E20 and P5 (8.10 \pm 0.25 cycles/min, $n=34)$, but the phrenic bursts were more variable in $\operatorname{Tg} 8$ preparations in terms of the cycle duration and amplitude (Fig. $1 B)$. The CVd at E20 was found to be slightly greater in $\mathrm{Tg} 8$ fetuses, but this difference was not significant. Although CVd then decreased with age in both strains (Fig. $1 C, D$ ), the mean $\mathrm{CVd}$ was greater in $\mathrm{Tg} 8$ than in $\mathrm{C} 3 \mathrm{H}$ neonates at $\mathrm{P} 0-\mathrm{P} 5$ (Fig. $1 E)$. The amplitudes of the integrated phrenic bursts evolved in a similar way, showing a high coefficient of variability in fetuses of both strains at E20 $(0.42 \pm 0.03, n=8)$. This coefficient then decreased at birth but was greater in $\mathrm{Tg} 8$ than in $\mathrm{C} 3 \mathrm{H}$ neonates at P0-P2 $(0.38 \pm 0.04, n=21$ vs $0.24 \pm 0.04, n=18)$ and P3-P5 $(0.26 \pm 0.03, n=9$ vs $0.17 \pm 0.03, n=11)$.

MAOA deficiency increases both 5-HT and norepinephrine levels (Cases et al., 1995). To determine whether the abnormal variability of the $\operatorname{Tg} 8$ phrenic bursts is attributable to $5-\mathrm{HT}$ excess, we administered the 5-HT synthesis inhibitor PCPA, either from P0 to P3 or from E18 to birth. Postnatal PCPA treatment did not significantly affect the mean $\mathrm{CVd}$ in $\mathrm{Tg} 8$ preparations at $\mathrm{P} 3-\mathrm{P} 5(0.27 \pm 0.05, n=3)$ compared with control Tg8 neonates $(0.30 \pm 0.04, n=9)$, whereas prenatal PCPA treatment significantly decreased the CVd (Fig. $1 F)$. Tg8 neonates born from PCPA-treated dams showed more stable cycle durations at $\mathrm{P} 0-\mathrm{P} 2$, with lower $\mathrm{CVd}(0.30 \pm 0.06, n=4)$ than $\mathrm{Tg} 8$ neonates born from control dams $(0.46 \pm 0.03, n=21)$. The fact that the $\mathrm{CVd}$ of these prenatally treated $\mathrm{Tg} 8$ neonates was comparable with that of $\mathrm{C} 3 \mathrm{H}$ neonates $(0.30 \pm 0.03, n=18)$ suggests that 5-HT excess is responsible for the $\mathrm{CVd}$ alterations observed in $\mathrm{Tg} 8$ preparations. In addition, the effects of prenatal PCPA indicates that the greater variability of the cycle durations observed in $\mathrm{Tg} 8$ neonates is of developmental origin. $\mathrm{C} 3 \mathrm{H}$ neonates born from PCPA-treated dams showed very variable cycle durations at $\mathrm{P} 0-\mathrm{P} 2$, and their $\mathrm{CVd}$ were higher $(0.71 \pm 0.09, n=5)$ than those of $\mathrm{C} 3 \mathrm{H}$ neonates born from control dams $(0.30 \pm 0.03$, $n=18$ ). The changes in the neonatal respiratory pattern observed in response to both increases and decreases in the 5-HT levels during the prenatal period show that 5-HT plays a crucial role in the maturation of the central respiratory network.

We then investigated whether the $\mathrm{Tg} 8$ variability may be mediated by the $5-\mathrm{HT}_{2 \mathrm{~A}} \mathrm{R}$. To mimic in $\mathrm{C} 3 \mathrm{H}$ fetuses the intense activation of the $5-\mathrm{HT}_{2 \mathrm{~A}} \mathrm{R}$ that probably occurs in $\mathrm{Tg} 8$ fetuses because of the high 5-HT levels, we administered the $5-\mathrm{HT}_{2 \mathrm{~A}} \mathrm{R}$ agonist DOI to pregnant $\mathrm{C} 3 \mathrm{H}$ dams from $\mathrm{E} 18$ to delivery. Conversely, to prevent activation of the $5-\mathrm{HT}_{2 \mathrm{~A}} \mathrm{R}$ in the $\mathrm{Tg} 8$ fetuses, we applied the 5- $\mathrm{HT}_{2 \mathrm{~A}} \mathrm{R}$ antagonist SR46349B to Tg8 dams.

Prenatal DOI treatment of $\mathrm{C} 3 \mathrm{H}$ dams (Fig. $1 F$ ) significantly increased the mean CVd in P0-P2 neonates $(0.43 \pm 0.03, n=4)$

$\leftarrow$

with PCPA (300 mg/kg per $24 \mathrm{hr})$ and $\mathrm{C} 3 \mathrm{H}$ neonates $(n=5)$ born from dams treated with the $5-\mathrm{HT}_{2 \mathrm{~A}} \mathrm{R}$ agonist DOI $(50 \mathrm{mg} / \mathrm{kg}$ per $24 \mathrm{hr})$ than in control $\mathrm{C} 3 \mathrm{H}$ neonates $(n=18)$ born from untreated dams. Conversely, mean CVd is significantly lower both in Tg8 neonates $(n=4)$ born from dams treated with PCPA $(300 \mathrm{mg} / \mathrm{kg}$ per $24 \mathrm{hr})$ and in $\mathrm{Tg} 8$ neonates $(n=$ 5 ) born from dams treated with the $5-\mathrm{HT}_{2 \mathrm{~A}} \mathrm{R}$ antagonist SR46349B (50 $\mathrm{mg} / \mathrm{kg}$ per $24 \mathrm{hr})$ than in control neonates $(n=21)$ born from untreated dams. 
compared with control $\mathrm{C} 3 \mathrm{H}$ neonates $(0.30 \pm 0.03, n=18)$, whereas postnatal DOI treatment to $\mathrm{C} 3 \mathrm{H}$ pups from birth to $\mathrm{P} 2$ did not affect the mean CVd at P3-P5 $(0.22 \pm 0.05, n=5)$ compared with control $\mathrm{C} 3 \mathrm{H}$ pups $(0.19 \pm 0.02, n=11)$. Prenatal $5-\mathrm{HT}_{2 \mathrm{~A}} \mathrm{R}$ antagonist SR46349B treatment of Tg8 dams (Fig. $1 F$ ) significantly lowered the mean $\mathrm{CVd}$ in $\mathrm{P} 0-\mathrm{P} 2$ neonates $(0.38 \pm$ $0.05, n=5)$ compared with control Tg8 neonates $(0.46 \pm 0.03$, $n=21)$. Therefore, $5-\mathrm{HT}_{2 \mathrm{~A}} \mathrm{R}$ are likely contributors to the deleterious effects of 5-HT excess.

\section{Abnormal 5-HT modulation of respiratory activity in medulla-spinal cord preparations of Tg8 neonates}

As reported in rats and OF1 mice pups (Morin et al., 1991a; Lindsay and Feldman, 1993; Di Pasquale et al., 1994a, 1997; Monteau et al., 1994; Hilaire et al., 1997b), replacing normal aCSF by aCSF containing $25 \mu \mathrm{M} 5$-HT (4 min) in $\mathrm{P} 0-\mathrm{P} 3 \mathrm{C} 3 \mathrm{H}$ preparations $(n=16)$ increases the burst frequency by $23 \pm 5 \%$, induces a tonic discharge in the phrenic roots, and depresses the amplitude of the inspiratory bursts (Fig. 2A1), whereas 5-HT neither accelerated the frequency nor depressed the phrenic burst amplitude in $\operatorname{Tg} 8$ mice $(n=10)$ but still induced a tonic discharge (Fig. 2A2).

\section{Exogenous 5-HT and phrenic burst frequency}

In $\mathrm{P} 0-\mathrm{P} 3 \mathrm{C} 3 \mathrm{H}$ neonates, a dose-dependent increase in the burst frequency was elicited by applying 5-HT to the medulla alone (Fig. 2B). This increase probably resulted from the activation of $5-\mathrm{HT}_{1 \mathrm{~A}} \mathrm{R}$ (Fig. $2 C$ ), because it was prevented by a pretreatment with the $5-\mathrm{HT}_{1 \mathrm{~A}} \mathrm{R}$ antagonist NAN190 $(n=7)$ but not with the $5-\mathrm{HT}_{2 \mathrm{~A}} \mathrm{R}$ antagonist SR46349B $(n=5)$. The increase was mimicked by the 5 - $\mathrm{HT}_{1 \mathrm{~A}} \mathrm{R}$ agonist 8 -OH-DPAT $(34 \pm 8 \%, n=8)$ but not by the $5-\mathrm{HT}_{2 \mathrm{~A}} \mathrm{R}$ agonists $\alpha \mathrm{C} 3 \mathrm{H}-5$-HT $(n=5)$ and DOI $(n=$ 5 ). The increases in the burst frequency induced by 5-HT may reflect a permanent facilitatory modulation of the rhythm generator by endogenous 5-HT (Fig. 2D); the burst frequency decreased after blocking the 5-HT ${ }_{1 \mathrm{~A}} \mathrm{R}$ with an antagonist, namely NAN190 $(17 \pm 8 \%, n=9)$ or $p$-MPPI $(34 \pm 11 \%, n=7)$, but increased after activating 5-HT synthesis with the precursor L-tryptophan $(17 \pm 10 \%, n=7)$.

In P0-P3 Tg8 neonates, 5-HT did not affect the burst frequency, even at high concentrations (Fig. 2B). Furthermore, the 5-HT ${ }_{1 \mathrm{~A}} \mathrm{R}$ agonist 8-OH-DPAT, the two antagonists NAN190 $(n=9)$ and $p$-MPPI $(n=5)$ nor the 5-HT precursor L-tryptophan $(n=7)$ affected the Tg8 burst frequency (Fig. 2D). The 5-HT modulation of burst frequency was therefore lacking. However, depleting the endogenous 5-HT levels by applying PCPA treatments to Tg8 dams (from E18 to birth, $n=3$ ) or neonates (from birth to $\mathrm{P} 2, n=3$ ) restored the 5-HT facilitatory effects; the Tg8 burst frequency increased by $25 \pm 2 \%(n=6)$ under $25 \mu \mathrm{M} 5$-HT (Fig. 2D, black bar).

\section{Exogenous 5-HT and tonic discharges in phrenic roots}

5-HT also induced a tonic discharge in the phrenic roots with a 2-3 min latency in $\sim 70 \%$ of both $\mathrm{C} 3 \mathrm{H}$ and $\mathrm{Tg} 8 \mathrm{P} 0-\mathrm{P} 3$ neonates (Fig. 2A1,2A2). The tonic discharge reflected the activation of cervical receptors, because it could be elicited by applying 5-HT to the cervical cord alone. In addition, the receptors involved were probably of the $5-\mathrm{HT}_{2 \mathrm{~A}}$ type, because the discharge was elicited by $25 \mu \mathrm{M}$ of either the $5-\mathrm{HT}_{2 \mathrm{~A}} \mathrm{R}$ agonist $\alpha \mathrm{CH} 3-5-\mathrm{HT}$ $(n=3$ of 5$)$ or DOI $(n=3$ of 5$)$ but not by the $5-\mathrm{HT}_{1 \mathrm{~A}} \mathrm{R}$ agonist 8-OH-DPAT (30 $\mu \mathrm{M}, n=0$ of 5). Lastly, the tonic discharge was prevented by pretreatment with the $5-\mathrm{HT}_{2 \mathrm{~A}} \mathrm{R}$ antagonist
SR46349B (40 $\mu \mathrm{M}, n=0$ of 5) but not with the $5-\mathrm{HT}_{1 \mathrm{~A}} \mathrm{R}$ antagonist NAN190 (40 $\mu \mathrm{M}, n=5$ of 7$)$.

\section{Exogenous 5-HT and depression of phrenic burst amplitude}

During the 5-HT-induced tonic discharge, the amplitude of the inspiratory bursts decreased greatly in $\mathrm{C} 3 \mathrm{H}$ neonates, and the bursts were hardly discernible in the overall phrenic root recordings during the last minute of 5-HT application (Fig. 2A1). This effect did not involve either $5-\mathrm{HT}_{1 \mathrm{~A}} \mathrm{R}$ or $5-\mathrm{HT}_{2 \mathrm{~A}} \mathrm{R}$, because it still occurred after antagonist treatments with $20 \mu \mathrm{M}$ NAN190 $(n=5)$ and $40 \mu \mathrm{M}$ SR46349B $(n=5)$, respectively. This amplitude decrease might be mediated by cervical $5-\mathrm{HT}_{1 \mathrm{~B}} \mathrm{R}$, because the burst amplitude was depressed by applying the agonist RU24969 $(n=5)$ to the cervical cord (Fig. 2E). Furthermore, the 5-HTinduced amplitude depression was prevented by pretreatment with $40 \mu \mathrm{M} 5-\mathrm{HT}_{1 \mathrm{~B}} \mathrm{R}$ antagonist $(-)$ pindolol $(n=5)$. In contrast, in Tg8 neonates, the inspiratory bursts remained unchanged during 5-HT application (25 $\mu \mathrm{M}, n=10)$ (Fig. 2A2), and their amplitude was not affected by the $5-\mathrm{HT}_{1 \mathrm{~B}} \mathrm{R}$ agonist RU24969 $(n=5)$.

\section{Abnormally low expression of $5-\mathrm{HT}_{1 \mathrm{~A}}$ receptors in the brainstem and cervical cord of Tg8 neonates}

A comparative study on $\left[{ }^{3} \mathrm{H}\right] 8-\mathrm{OH}-\mathrm{DPAT}$ binding in the brainstem and cervical cord was performed on $\mathrm{C} 3 \mathrm{H}$ and $\mathrm{Tg} 8$ neonates at P7. Three distinct regions of the medulla were analyzed, namely the spinal trigeminal nucleus $(\mathrm{SpV})$, the hypoglossal area, and the ambiguus area. The $5-\mathrm{HT}_{1 \mathrm{~A}} \mathrm{R}$ density was also determined in the dorsal and ventral horns of the cervical cord. In $\mathrm{C} 3 \mathrm{H}$ pups, the highest densities were recorded in the $\mathrm{SpV}$ nucleus $(32.9 \pm 0.6 \mathrm{fmol} / \mathrm{mg}$ tissue $)$ and slightly lower values in the dorsal horn $(23.9 \pm 0.3 \mathrm{fmol} / \mathrm{mg}$ ) (Fig. $3 A)$; in the hypoglossal, ambiguus and ventral horn areas, the densities were approximately onethird of those measured in the SpV. In Tg8 pups, the 5-HT ${ }_{1 \mathrm{~A}} \mathrm{R}$ densities decreased by $>52 \%$ in all four areas tested compared with the $\mathrm{C} 3 \mathrm{H}$ pups (Fig. $3 B-E$ ). In the ventral horn of the cervical cord in which the PhMns are located, the $5-\mathrm{HT}_{1 \mathrm{~A}} \mathrm{R}$ density was only $\sim 5 \mathrm{fmol} / \mathrm{mg}$ tissue in Tg8 pups. The abnormally low level of expression of the $5-\mathrm{HT}_{1 \mathrm{~A}} \mathrm{R}$ observed in the mutant strain may therefore at least partly explain the loss of the respiratory frequency response to exogenous $5-\mathrm{HT}$ via $5-\mathrm{HT}_{1 \mathrm{~A}} \mathrm{R}$.

\section{Electrophysiological study on cervical neurons in $\mathrm{C} 3 \mathrm{H}$ and Tg8 neonates}

At the $\mathrm{C} 4$ level, the phrenic nucleus was explored in $\mathrm{C} 3 \mathrm{H}$ and $\mathrm{Tg} 8$ preparations at $\mathrm{P} 0-\mathrm{P} 3$ using whole-cell patch-clamp micropipettes; 186 neurons were tested and classified as either PhMns $(n=74)$ or interneurons $(n=112)$.

\section{Membrane properties of phrenic motoneurons}

Neurons were defined as being PhMns if they were antidromically activated by $\mathrm{C} 4$ ventral root stimulation (Fig. $4 A$ ) and if they fired during the phrenic bursts (Fig. $4 B$ ). Among the 74 PhMns recorded from, 54 were selected on the basis of the excellent quality of the recordings (seal of $>3 \mathrm{G} \Omega$, overshooting potentials, and stable recording). The $23 \mathrm{C} 3 \mathrm{H}$ and $31 \mathrm{Tg} 8 \mathrm{PhMns}$ tested did not differ significantly in their resting potentials during expiration $(-68 \pm 1 \mathrm{mV})$, spike amplitudes $(74 \pm 2 \mathrm{mV})$, spike half durations $(1.02 \pm 0.03 \mathrm{msec})$, or firing thresholds $(-51 \pm 1 \mathrm{mV})$. When driven above the firing threshold by $1 \mathrm{sec}$ depolarizing pulses, the PhMns fired a sustained burst of potentials (Fig. $4 C$ ), and the relationship between the intensity ( $I$, in picoamperes) of the depolarizing pulses and the frequency $(F$, in Hertz) of the 
A $A 1-C 3 H$

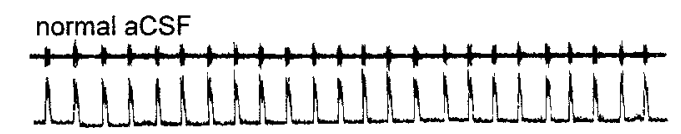

5-HT $(25 \mu \mathrm{M})$

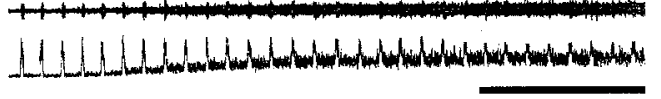

A2 - Tg8

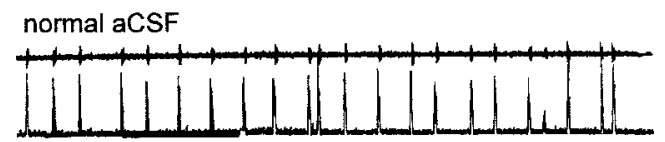

5-HT $(25 \mu \mathrm{M})$

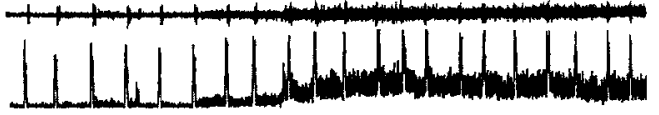

B
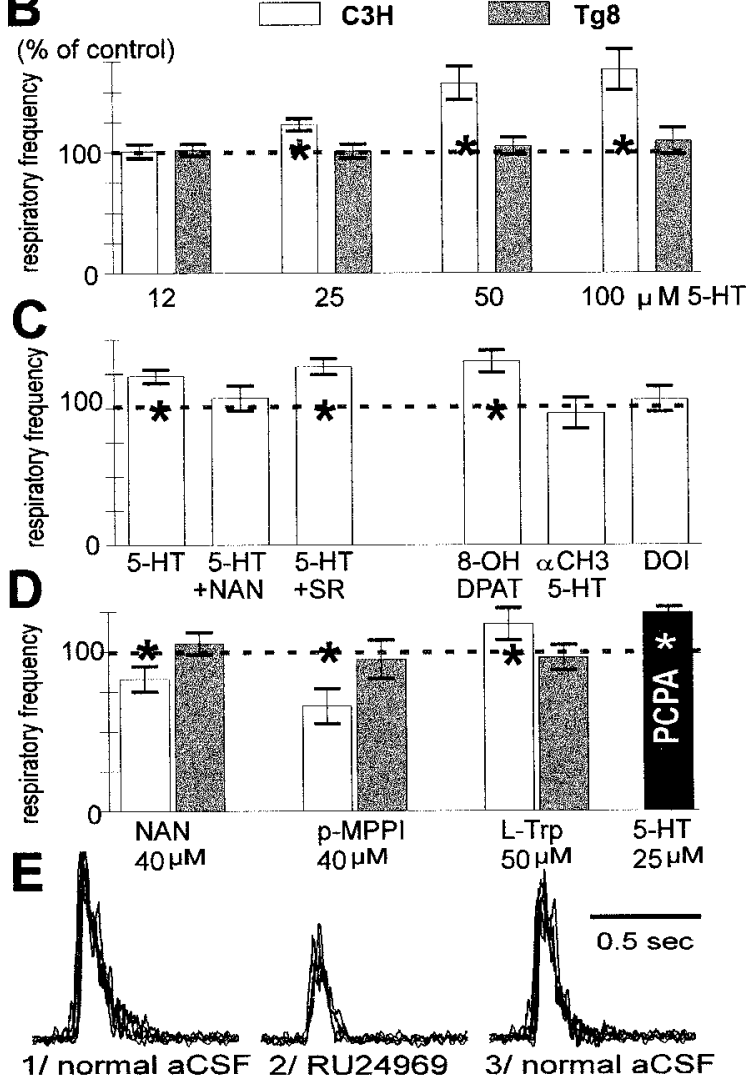

Figure 2. Serotonergic modulation of the phrenic activity in $\mathrm{C} 3 \mathrm{H}$ and $\mathrm{Tg} 8$ neonatal preparations. $A 1$, Phrenic discharge in $\mathrm{C} 3 \mathrm{H}$ preparations under normal aCSF (top and bottom traces are raw and integrated discharges, respectively). Adding $25 \mu \mathrm{M} 5$-HT induces a tonic discharge and increases the burst frequency but depresses their amplitude. A2, Applying aCSF added with 5-HT on Tg8 preparations induces only the tonic discharge. $B$, Increasing concentrations of 5-HT $(12-100 \mu \mathrm{M})$ induce a dose-dependent burst frequency increase in $\mathrm{C} 3 \mathrm{H}$ (white bars) but not in Tg8 (gray bars) preparations. Respiratory frequencies are mean \pm SEM percentages of control value. $\mathrm{C} 3 \mathrm{H}$ and $\mathrm{Tg} 8 n$ values, respectively: $12 \mu \mathrm{M}$, $n=5$ and $5 ; 25 \mu \mathrm{M}, n=16$ and $10 ; 50 \mu \mathrm{M}, n=5$ and $6 ; 100 \mu \mathrm{M}, n=5$ and $5 .{ }^{*} p<0.05$. $C$, The 5-HT-induced respiratory frequency increase in $\mathrm{C} 3 \mathrm{H}$ preparations is mediated by $5-\mathrm{HT}_{1 \mathrm{~A}} \mathrm{R}$. The $25 \mu \mathrm{M} 5-\mathrm{HT}$ increase $(5-H T ; n=16)$ is blocked by the $5-\mathrm{HT}_{1 \mathrm{~A}} \mathrm{R}$ antagonist NAN190 at $40 \mu \mathrm{M}$ $(5-H T+N A N ; n=7)$ but not by the $5-\mathrm{HT}_{2 \mathrm{~A}} \mathrm{R}$ antagonist SR46349B at $40 \mu \mathrm{M}(5-H T+S R ; n=5)$. The 5- $\mathrm{HT}_{1 \mathrm{~A}} \mathrm{R}$ agonist 8-OH-DPAT at $30 \mu \mathrm{M}$ potentials was identical in both strains $(I-F$ slope, $0.15 \pm 0.01$ $\mathrm{pA} / \mathrm{Hz}$ ). The membrane input resistance $R$ was calculated from the membrane voltage changes $V$ elicited by $1 \mathrm{sec}$ hyperpolarizing pulses with an increasing stepped intensity $I$ (Fig. $4 D$ ) in line with the relationship $r=V / I$. The membrane input resistance of $\mathrm{PhMns}$ was found to be larger in $\mathrm{C} 3 \mathrm{H}(94 \pm 10 \mathrm{M} \Omega)$ than in $\mathrm{Tg} 8$ $(68 \pm 7 \mathrm{M} \Omega)$ neonates (Fig. $4 E)$.

\section{Respiratory discharges of phrenic motoneurons}

In both strains, the PhMns were silent during expiration, depolarized by the central inspiratory drive $(10-20 \mathrm{mV})$, and fired a sustained burst of potentials during inspiration. The amplitudes of the inspiratory depolarizations imposed by the central drivers and the resulting spike patterns were stable in $\mathrm{C} 3 \mathrm{H}$ PhMns. In Tg8 PhMns, on the contrary, the spike discharge varied from one inspiration to the next (Fig. $4 F$ ); a Tg8 PhMn could fire normally, deliver only a few action potentials, or fire a long, sustained burst of potentials. Because PhMns are known to be monosynaptically controlled by their central drivers (Monteau and Hilaire, 1991), the variability of the Tg8 PhMn discharges may have originated from variations in (1) the central drive they received, (2) its transmission to $\mathrm{PhMns}$, or (3) the $\mathrm{PhMn}$ responsiveness.

In both $\mathrm{C} 3 \mathrm{H}$ and $\mathrm{Tg} 8$ neonates, PhMns produced stable bursts of potentials in response to repetitive depolarizing pulses applied during expiration with a constant intensity. The Tg8 burst variability was therefore not attributable to variations in $\mathrm{PhMn}$ responsiveness. When PhMns were silenced by a hyperpolarization imposed on their membrane $(-120 \mathrm{mV})$ so that the inspiratory depolarizations evoked by the central drivers failed to reach the firing threshold, the inspiratory depolarizations occurred without any superimposed spiking. They were stable from one inspiration to the next in $\mathrm{C} 3 \mathrm{H}$ but variable in $\mathrm{Tg} 8 \mathrm{PhMns}$. The fact that the time course of the synaptic drive potential was found to mirror the underlying synaptic drive current measured using the voltageclamp technique (Liu et al., 1990) means that the synaptic drive current received by the PhMns was variable in Tg8 neonates.

In addition, the spiking variations in a given Tg8 PhMn perfectly reflected the amplitude variations of the integrated phrenic bursts (Fig. 4F). This means that all of the Tg8 PhMns showed the same concomitant variations in their patterns of activity. If some failure of the synaptic transmission to PhMns had been responsible for the changes in burst amplitude, it would have been simultaneous in all the PhMns, but this possibility seems rather unlikely. The variability of the Tg8 discharges therefore originated from the variability of the central drive impinging on the PhMns. At birth, the Tg8 respiratory centers were able to gener-

$\leftarrow$

$(8-O H D P A T ; n=8)$ mimicked the 5-HT increase, whereas the $5-\mathrm{HT}_{2 \mathrm{~A}} \mathrm{R}$ agonists at $25 \mu \mathrm{M} \alpha \mathrm{CH} 3-5 \mathrm{HT}(n=5)$ and DOI $(n=5)$ did not. $D$, In C3H preparations (white bars), the respiratory frequency is decreased by the two 5 - $\mathrm{HT}_{1 \mathrm{~A}} \mathrm{R}$ antagonists NAN190 $(n=9)$ and $p$-MPPI $(n=7)$ at $40 \mu \mathrm{M}$ but is increased by the 5-HT precursor L-Trp at $50 \mu \mathrm{M}(n=7)$. In Tg8 preparations ( gray bars), NAN190 $(n=9), p$-MPPI $(n=5)$, nor L-Trp $(n=7)$ have significant effects on respiratory frequency, but PCPA treatments (black bar; $n=6)$ performed before $(n=3)$ and after birth $(n=3)$ restored the respiratory frequency increase in response to $25 \mu \mathrm{M}$ exogenous 5 -HT that was observed in $\mathrm{C} 3 \mathrm{H}$ mice $(C, 5-H T)$. E. Activation of the cervical 5- $\mathrm{HT}_{1 \mathrm{~B}} \mathrm{R}$ depressed the amplitude of the phrenic bursts in $\mathrm{C} 3 \mathrm{H}$ preparations. A partition placed at the medullo-spinal junction (see horizontal arrows in Fig. $1 \mathrm{~A}$ ) was used to bathe the medulla with normal $\mathrm{aCSF}$ and the spinal cord successively with (1) normal aCSF, (2) aCSF containing the $5-\mathrm{HT}_{1 \mathrm{~B}} \mathrm{R}$ agonist RU24969 $(40 \mu \mathrm{M})$, and (3) normal aCSF again (15 min later). Phrenic burst integrates, five superimposed traces. 


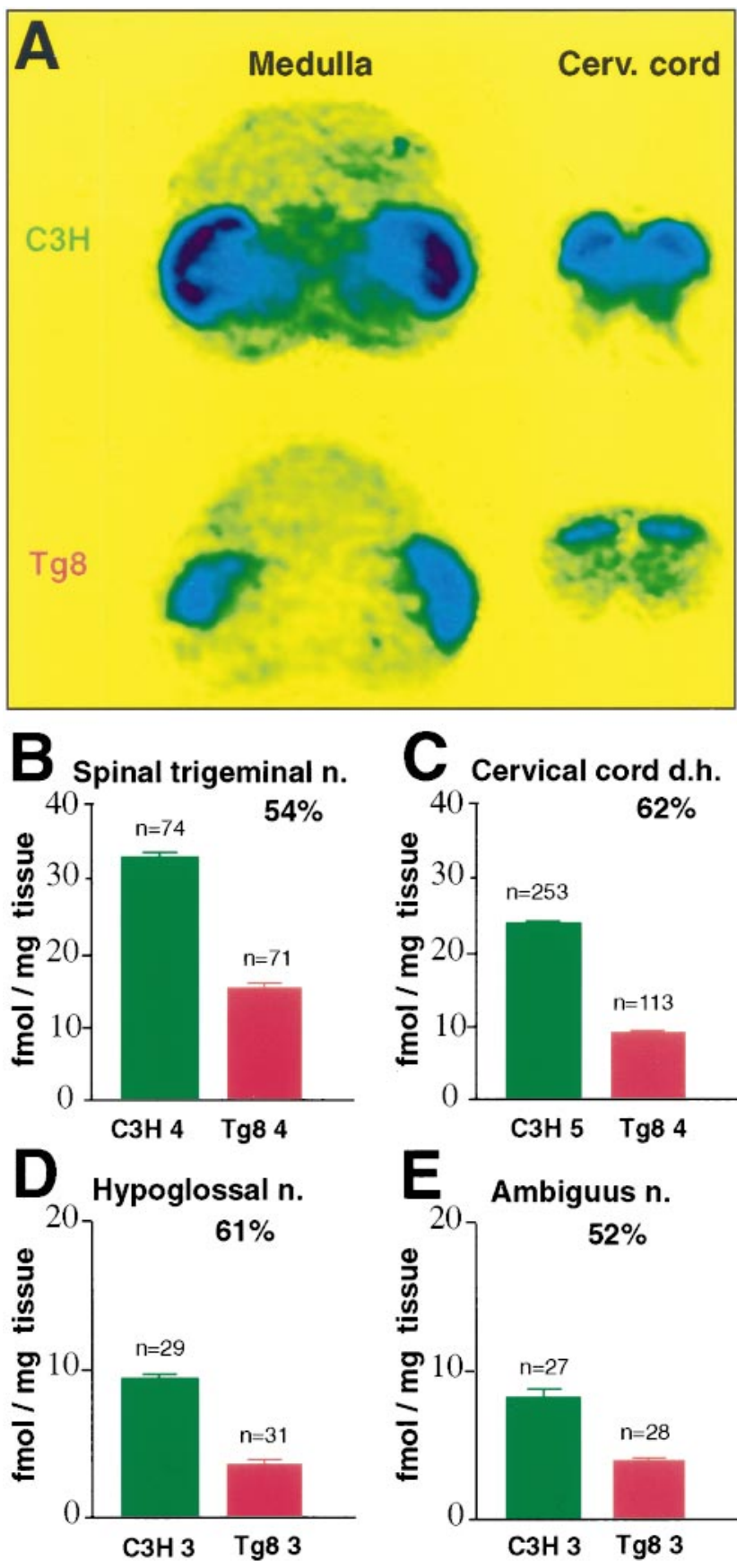

Figure 3. $5-\mathrm{HT}_{1 \mathrm{~A}}$ receptor binding is lower in the medulla and cervical cord of $\operatorname{Tg} 8$ mutant neonates than in the $\mathrm{C} 3 \mathrm{H}$ wild-type strain. $A$, Labeling of $5-\mathrm{HT}_{1 \mathrm{~A}} \mathrm{R}$ with $\left[{ }^{3} \mathrm{H}\right] 8-\mathrm{OH}-\mathrm{DPAT}$ on coronal sections of the medulla and spinal cervical cord from control wild $(\mathrm{C} 3 \mathrm{H})$ and mutant (Tg8) neonates at $\mathrm{P} 7$. In the $\mathrm{C} 3 \mathrm{H}$ mice, the greatest densities were recorded in the spinal trigeminal nucleus (Medulla, dark blue) and the dorsal horn of the cervical cord (Cerv. cord). In Tg8, the labeling was lighter in all the structures present in the brainstem and cervical cord sections. $B-E$, Quantitative analysis of the decrease in the specific binding in four distinct areas, i.e., the spinal trigeminal nucleus $(B)$, the dorsal horn of the cervical cord $(C)$, the hypoglossal nucleus $(D)$, and the ambiguus nucleus $(E)$. The bar in each histogram gives the $5-\mathrm{HT}_{1 \mathrm{~A}} \mathrm{R}$ density in $\mathrm{C} 3 \mathrm{H}$ ( green) and $\mathrm{Tg} 8$ (red) pups, expressed as the mean $\pm \mathrm{SEM}$ in femtomoles per milligram of tissue of the total number of sections analyzed $(n)$, based on three to five individuals of each strain. The mean decrease in the $5-\mathrm{HT}_{1 \mathrm{~A}} \mathrm{R}$ density in each area is expressed as a percentage, based on the ratio $([\mathrm{C} 3 \mathrm{H}-\mathrm{Tg} 8]: \mathrm{C} 3 \mathrm{H})$. The decrease ranges between 52 and $62 \%$, whether the structures initially exhibit a relatively high $(B, C)$ or low $(D, E)$ density in $\mathrm{C} 3 \mathrm{H}$ neonates.
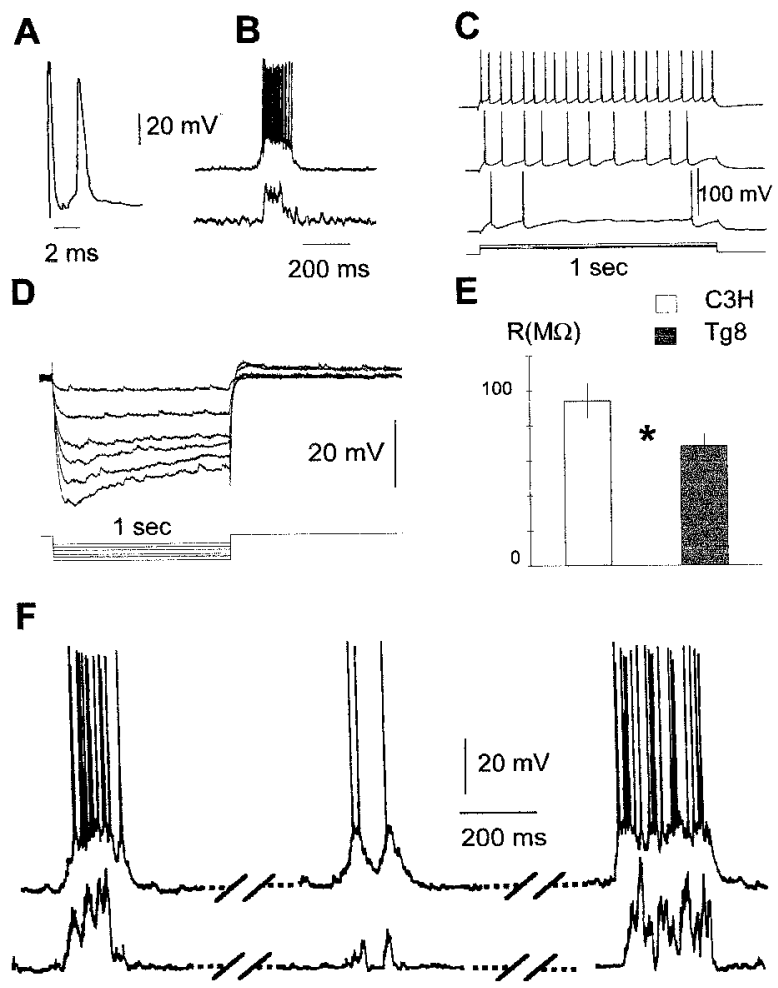

Figure 4. Membrane properties and firing pattern of phrenic motoneurons in $\mathrm{C} 3 \mathrm{H}$ and $\mathrm{Tg} 8$ neonatal preparations at $\mathrm{P} 0-\mathrm{P} 3 . A-C$, Identification and firing threshold of $\mathrm{PhMns}$ in either $\mathrm{C} 3 \mathrm{H}$ or $\mathrm{Tg} 8$ preparations. Antidromic action potential $(A)$ and spontaneous firing $(B)$ (top and bottom traces, $\mathrm{PhMn}$ intracellular recording and integrated phrenic burst, respectively), both recorded with a view to $\mathrm{PhMn}$ identification. $C$, Train of spikes induced in the same PhMn by applying $1 \mathrm{sec}$ depolarizing pulses during expiration at various intensities $(150,100$, and $40 \mathrm{pA}$ pulses, top to bottom). The firing threshold was defined as the voltage to which the PhMn has to be brought to deliver its first action potential. Above the threshold, the ratio between the frequency $F$ of the spikes in the train and the intensity $I$ of the injected current gives the $I-F$ slope. $D, E$, The membrane input resistance is significantly lower in Tg8 PhMn. D, The shifts in the membrane potentials induced by applying $1 \mathrm{sec}$ hyperpolarizing pulses with increasing intensities were used to calculate the membrane input resistance $(r=V / I)$. E, Membrane input resistance of PhMns expressed as mean $\pm \mathrm{SEM}$ in $\mathrm{C} 3 \mathrm{H}$ (white bar; $n=23$ ) and $\mathrm{Tg} 8$ (gray bar; $n=31$ ) preparations. ${ }^{*} p<0.05 . F$, Whole-cell patch-clamp recordings of a Tg8 PhMn (top trace) and integrated phrenic burst (bottom trace) illustrating the variability of the phrenic discharges in Tg8 preparations. Three successive inspirations are shown, with the expirations truncated. During the first inspiration, the PhMn activity seems quite normal at both unitary and overall levels; during the next inspiration, the PhMn tested delivers only three action potentials and the integrated phrenic burst is very weak; during the last one, the PhMn fires a long, sustained burst of potentials and the integrated overall discharge is also stronger.

ate neither a stable rhythm nor a respiratory command with a stable amplitude.

Scarcity of respiratory interneurons in the Tg8 phrenic nucleus The neurons in the $\mathrm{C} 4$ ventral horn that were not antidromically activated by $\mathrm{C} 4$ ventral root stimulation were classified as cervical interneurons. They had less highly polarized resting potentials $(47 \pm 1 \mathrm{mV})$ and threefold higher membrane input resistances (364 $\pm 32 \mathrm{M} \Omega$ ) than PhMns. They were further subclassified into "respiratory" and "nonrespiratory" interneurons on the basis of their discharge patterns. In $\mathrm{C} 3 \mathrm{H}$ neonates, 49 interneurons were identified, 12 of which (18\% of the sample) displayed a 
respiration-modulated activity. In $\operatorname{Tg} 8$ neonates, 62 of the 63 interneurons tested were nonrespiratory. Only one interneuron showed respiration-modulated activity (1.6\%). The difference between the frequency of occurrence of respiratory interneurons in $\mathrm{C} 3 \mathrm{H}$ versus $\mathrm{Tg} 8$ was significant $\left(\chi^{2}=8.960, p=0.003\right)$. There are several possible reasons why we observed very few interneurons firing with a respiratory modulation in the cervical cord of Tg8 mice. First, the presence of a sampling bias or some unknown technical cause cannot be completely ruled out. Second, the cervical respiratory interneurons exist in Tg8 mice, but they are located elsewhere within the cervical cord, probably at a more dorsal site, because we extensively explored the ventral horn. Third, these cervical interneurons may exist and be in the right place but may be rare because only a few of them have been contacted by the central respiratory drivers. This may mean either that the axons of the central drivers may project far from their normal place or that competition may exist between the cervical targets, i.e., the endings of the axon central drivers that should have contacted the cervical interneurons have in fact mainly contacted the abnormally numerous dendrites of PhMns in Tg8 instead of the cervical interneurons. Although negative results should always be treated with caution, the lack of Tg8 respiratory cervical interneurons observed here probably reflected their scarcity in the cervical ventral horn, which argues in favor of the idea that there exists an abnormal pattern of wiring between the medullary centers and their cervical targets.

\section{The phrenic motoneuron morphology differs between C3H and Tg8 neonates}

A total number of $22 \mathrm{PhMns}$ (10 in $\mathrm{C} 3 \mathrm{H}$ and 12 in Tg8 preparations at $\mathrm{P} 0-\mathrm{P} 3)$ were stained with biocytin. Their soma were located in the same region of the $\mathrm{C} 4$ ventral horn, and their frontal area was $\sim 300 \mu \mathrm{m}^{2}\left(262 \pm 28 \mu \mathrm{m}^{2}\right.$ and $283 \pm 32 \mu \mathrm{m}^{2}$, for $\mathrm{C} 3 \mathrm{H}$ and $\mathrm{Tg} 8 \mathrm{PhMns}$, respectively). $\mathrm{C} 3 \mathrm{H}$ and $\mathrm{Tg} 8 \mathrm{PhMns}$ showed obvious morphological differences in the pattern and extent of their dendritic trees (Fig. 5). In $\mathrm{C} 3 \mathrm{H}$ PhMns, most of the primary dendrites extended in two main directions (dorsolateral and ventromedial), forming a bipolar tree, although one to two primary short dendrites occasionally extended for a short distance in the dorsomedial direction, sometimes giving rise to a few secondary dendrites (Fig. 5A). In Tg8 PhMns, the bipolar dendritic tree was replaced by a multipolar tree (Fig. $5 B$ ). The primary dendrites extended in all possible directions and gave rise to numerous distal dendrites. The length and number of proximal dendrites were in the same range in $\mathrm{C} 3 \mathrm{H}$ and $\mathrm{Tg} 8$ pups; six to seven primary-order dendrites and 11-12 second-order dendrites were detected in both strains, each of which extended for a distance of 25-40 $\mu \mathrm{m}$. However, the Mann-Whitney $U$ test for two independent groups showed that the number of distal dendrites $(\sim 40 \mu \mathrm{m}$ in length) was significantly greater in Tg8 $(18 \pm 6,15 \pm 6$, and $13 \pm 7$ for dendrites of orders three, four, and five, respectively) than in $\mathrm{C} 3 \mathrm{H}$ neonates $(8 \pm 3,6 \pm 3$, and $1 \pm 5)$. The total extent of the dendritic tree was therefore greater in $\operatorname{Tg} 8$ than in $\mathrm{C} 3 \mathrm{H}$ PhMns (Fig. 5E); this modification is in agreement with the observed reduction in the membrane input resistance. Both $\mathrm{C} 3 \mathrm{H}$ and Tg8 PhMns possessed dendritic spines (Fig. 5C) and swollen varicosities (Fig. $5 D$ ), but these features were rare in $\mathrm{C} 3 \mathrm{H}$ and much more frequent in $\mathrm{Tg} 8$ (Fig. $5 F, G$ ).

\section{5-HT excess, 5- $\mathrm{HT}_{2 \mathrm{~A}}$ receptors, and phrenic motoneuron morphology}

Pharmacological treatments were applied to fetuses and neonates to determine whether the abnormal morphology observed in Tg8
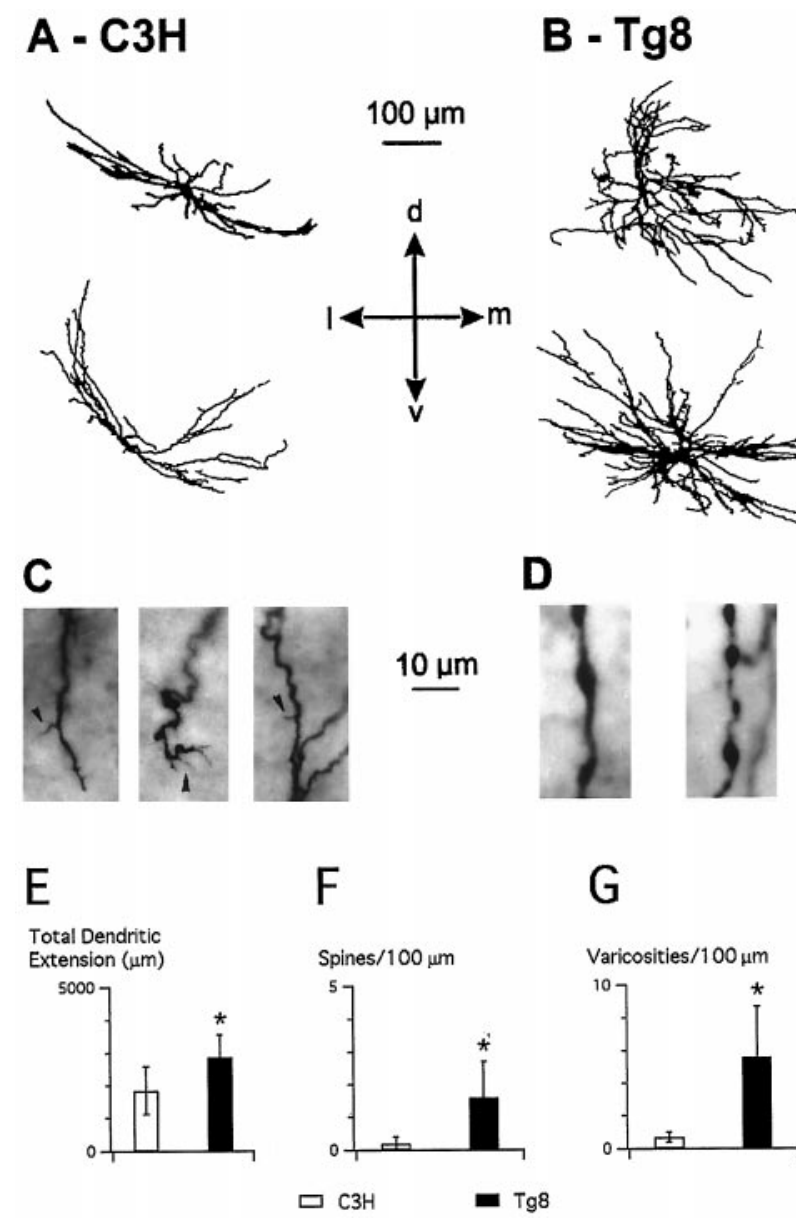

G

Figure 5. Dendritic morphology of phrenic motoneurons differs between $\mathrm{C} 3 \mathrm{H}$ and $\mathrm{Tg} 8$ neonates at $\mathrm{P} 0-\mathrm{P} 3 . A, B$, Camera lucida drawings of two biocytin-stained PhMns exhibiting a bipolar dendritic tree in $\mathrm{C} 3 \mathrm{H}(A)$ but a multipolar dendritic tree in $\operatorname{Tg} 8(B)$ neonates. Directional bars: $d$, dorsal; $v$, ventral; $l$, lateral; $m$, medial. $C, D$, Light microscopic images showing that Tg8 PhMn dendrites possess many spines ( $C$, arrowheads) and swollen varicosities $(D)$. Immersion objective, $100 \times . E-G$, The dendritic extent and number of both spines and varicosities are significantly greater in Tg8 (black bars; $n=12$ ) than in $\mathrm{C} 3 \mathrm{H}$ (white bars; $n=10$ ) PhMns. The total dendritic extent $(E)$ is $2878 \pm 670 \mu \mathrm{m}$ in $\mathrm{Tg} 8$ versus $1858 \pm 730 \mu \mathrm{m}$ in $\mathrm{C} 3 \mathrm{H}$. The number of spines $(F)$ is $1.6 \pm 1.1$ in $\mathrm{Tg} 8$ versus $0.2 \pm 0.2$ in $\mathrm{C} 3 \mathrm{H}$ and that of varicosities $(G)$ is $5.6 \pm 3.1$ in $\mathrm{Tg} 8$ versus $0.7 \pm 0.3 \mathrm{in}$ $\mathrm{C} 3 \mathrm{H}$, both per $100 \mu \mathrm{m}$ of dendritic length. Median value \pm quartile deviation. $* p<0.05$.

PhMns was attributable to the 5-HT excess. First, to mimic in $\mathrm{C} 3 \mathrm{H}$ neonates the postnatal 5-HT excess present in the Tg8 strain, $\mathrm{C} 3 \mathrm{H}$ preparations at $\mathrm{P} 0-\mathrm{P} 3$ were superfused with aCSF containing $200 \mu \mathrm{M} 5$-HT for $\sim 2 \mathrm{hr}$. The 5-HT-treated $\mathrm{C} 3 \mathrm{H}$ PhMns were then injected with biocytin, and their morphology was compared with that of the control $\mathrm{C} 3 \mathrm{H}$ PhMns. Among the seven stained $\mathrm{PhMns}$, five still showed a bipolar dendritic tree, but two others had dendrites running in unexpected directions (Fig. $6 A$, arrow). The Kruskal-Wallis test and Dunnett's method were used to compare the three groups (treated $\mathrm{C} 3 \mathrm{H}$ PhMns vs $\mathrm{C} 3 \mathrm{H}$ and Tg8 control PhMns). The number and length of the proximal dendrites were not affected by the 5-HT treatment, but the number of order 4 dendrites was significantly larger, reaching the Tg8 range $(15 \pm 4)$. The total extent of the dendritic trees of the 5-HT-treated $\mathrm{PhMns}$ was slightly larger than the $\mathrm{C} 3 \mathrm{H}$ control value, but the difference was not significant (Fig. 6B). The frequency of occur- 


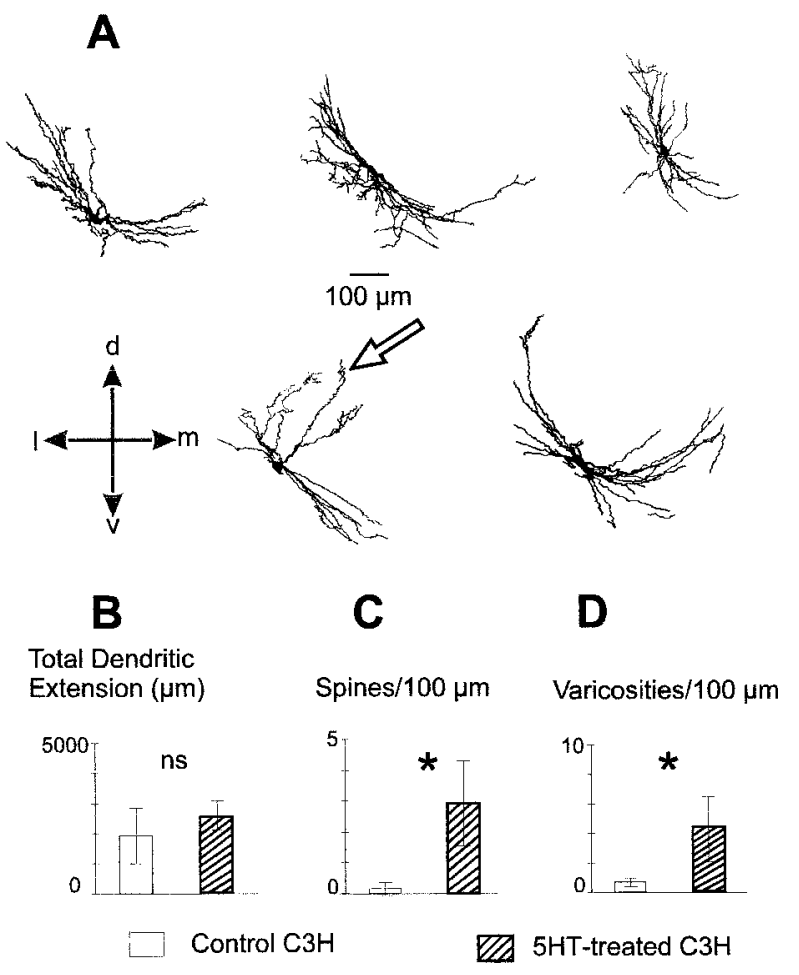

Figure 6. The dendritic morphology of phrenic motoneurons in $\mathrm{C} 3 \mathrm{H}$ neonates at $\mathrm{P} 0-\mathrm{P} 3$ is affected by $5-\mathrm{HT}$ excess. $A$, Camera lucida drawings of five biocytin-stained $\mathrm{PhMns}$ in $\mathrm{C} 3 \mathrm{H}$ preparations superfused with 5-HT (200 $\mu \mathrm{M}, 2 \mathrm{hr})$. Among the seven PhMns stained, five still show a bipolar dendritic tree, but two have a few main dendrites running in unexpected directions (arrow). B-D, 5-HT-treated C3H PhMns (hatched bars; $n=7$ ) are compared with control C3H PhMns (white bars; $n=10$ ). The total dendritic extent was not affected by 5 -HT treatment $(B)$, whereas the number of dendritic spines $(C)$ and varicosities $(D)$ increased significantly after applying 5 -HT, reaching $2.7 \pm 1.5$ spines and $4.2 \pm 2.1$ varicosities per $100 \mu \mathrm{m}$ of dendritic length. These changes were prevented by blocking $5-\mathrm{HT}_{2 \mathrm{~A}} \mathrm{R}$ with the antagonist SR46349B. Median values \pm quartile deviation; $n s$, nonsignificant; * $p<0.05$.

rence of dendritic spines and varicosities was much greater in the treated $\mathrm{C} 3 \mathrm{H} \mathrm{PhMns}$ than in the control $\mathrm{C} 3 \mathrm{H} \mathrm{PhMns}$, however, reaching similar levels to those recorded in Tg8 PhMns (Fig. 6C,D).

In a second set of experiments, $\mathrm{C} 3 \mathrm{H}$ preparations were pretreated with the 5- $\mathrm{HT}_{2 \mathrm{~A}} \mathrm{R}$ antagonist SR43349B $(80 \mu \mathrm{M})$ for $1 \mathrm{hr}$, and the PhMns were then stained under aCSF containing both 5-HT $(200 \mu \mathrm{M})$ and the 5- $\mathrm{HT}_{2 \mathrm{~A}} \mathrm{R}$ antagonist SR46349B $(80 \mu \mathrm{M})$. None of the four stained PhMns were morphologically affected by 5-HT application; the pattern of the dendritic trees, the total dendritic extent, nor the frequency of occurrence of the dendritic spines and varicosities differed from the control values.

In the third set of experiments, we mimicked in $\mathrm{C} 3 \mathrm{H}$ fetuses the overactivation of the $5-\mathrm{HT}_{2 \mathrm{~A}} \mathrm{R}$ occurring in $\mathrm{Tg} 8$ fetuses. Pregnant $\mathrm{C} 3 \mathrm{H}$ mice were treated with the $5-\mathrm{HT}_{2 \mathrm{~A}} \mathrm{R}$ agonist DOI from E18 to birth. Of four PhMns stained at P0, only one PhMn still showed a typical $\mathrm{C} 3 \mathrm{H}$ dendritic tree, whereas the other three PhMns showed a multipolar-shaped dendritic tree (Fig. 7A). The total dendritic extent was greater than that of the control $\mathrm{C} 3 \mathrm{H}$ PhMns and was in the Tg8 range (Fig. 7C). The number of distal dendrites differed from the $\mathrm{C} 3 \mathrm{H}$ control value and was in the $\mathrm{Tg} 8$ range $(25 \pm 4,25 \pm 4$, and $16 \pm 7$ for dendrites of orders 3,4 and 5 , respectively). The frequency of occurrence of dendritic spines and varicosities was larger than the $\mathrm{C} 3 \mathrm{H}$ control value but similar
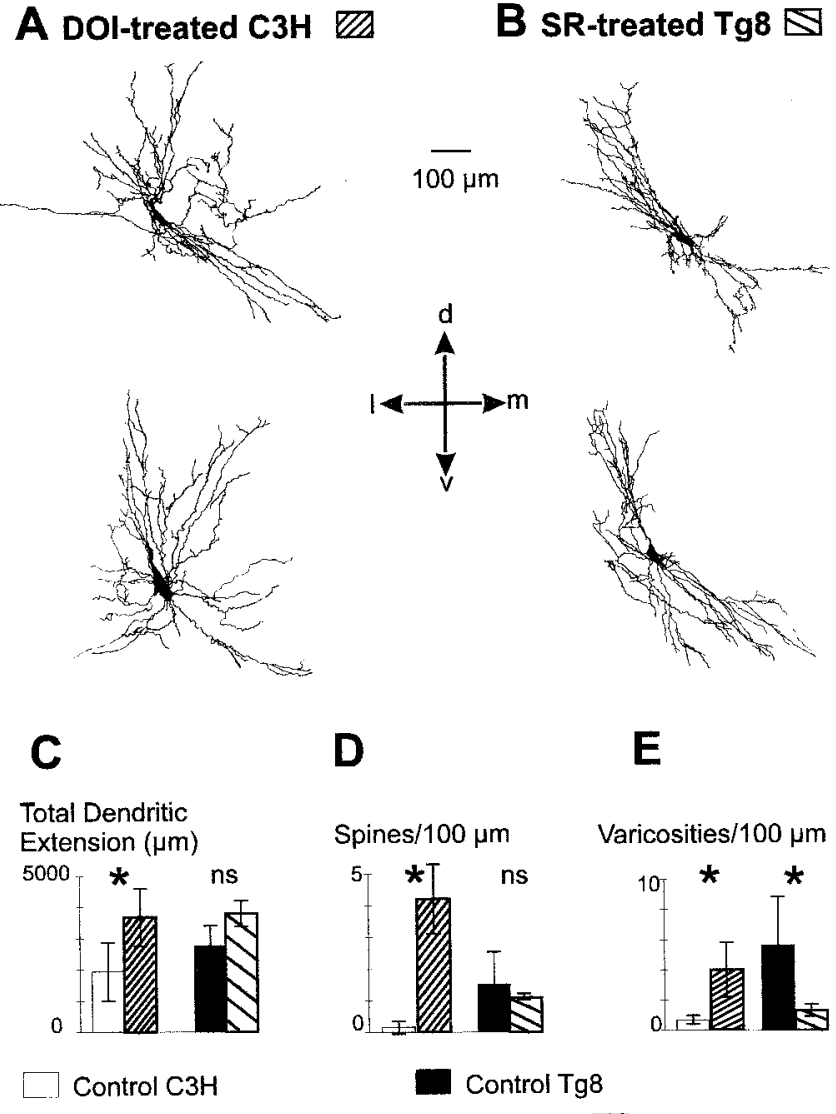

Z DOI-treated $\mathrm{C} 3 \mathrm{H}$

$\triangle$ SR-treated Tg8

Figure 7. The morphology of phrenic motoneurons at birth is affected by prenatal activation and blockade of $5-\mathrm{HT}_{2 \mathrm{~A}}$ receptors. $A, B$, Camera lucida drawings of biocytin-stained PhMns in $\mathrm{P} 0$ neonates after prenatal treatment $(50 \mathrm{mg} / \mathrm{kg}$ per $24 \mathrm{hr})$ from gestational day E18 to birth with either the $5-\mathrm{HT}_{2 \mathrm{~A}} \mathrm{R}$ agonist DOI applied to $\mathrm{C} 3 \mathrm{H}$ dams $(A)$ or the 5- $\mathrm{HT}_{2 \mathrm{~A}} \mathrm{R}$ antagonist SR46349B applied to Tg8 dams $(B)$. Prenatal activation and blockade of $5-\mathrm{HT}_{2 \mathrm{~A}} \mathrm{R}$ affect the shape of the $\mathrm{PhMn}$ dendritic tree at birth; after applying DOI-treatment to $\mathrm{C} 3 \mathrm{H}$ fetuses, three of the four PhMns stained showed a Tg8-like multipolar dendritic tree $(A)$, whereas after applying SR46349B-treatment to Tg8 fetuses, all of the six Tg8 PhMns stained exhibited a C3H-like bipolar tree $(B)$. $C-E$, DOItreated $\mathrm{C} 3 \mathrm{H}$ PhMns (narrow-hatched bars; $n=4$ ) versus nontreated control C3H PhMns (white bars; $n=10$ ), and SR46349B-treated Tg8 PhMns (hatched bars; $n=6$ ) versus nontreated control Tg8 PhMns (black bars; $n=12$ ). DOI treatment significantly increases the total dendritic extent of $\mathrm{C} 3 \mathrm{H}$ PhMns $(3663 \pm 922 \mu \mathrm{m})$, as well as the number of both dendritic spines $(4.2 \pm 1.1)$ and varicosities $(4.0 \pm 1.8)$ per $100 \mu \mathrm{m}$ of dendritic length. SR46349B treatment affects neither the total dendritic extent of Tg8 PhMns nor the number of spines but decreases the number of varicosities $(1.3 \pm 0.4)$ per $100 \mu \mathrm{m}$ of dendritic length. Median values \pm quartile deviation; $n s$, nonsignificant; ${ }^{*} p<0.05$.

to the $\operatorname{Tg} 8$ one (Fig. $7 D, E$ ). On the other hand, pregnant Tg8 dams were treated with the antagonist SR46349B from gestational day E18 to birth to prevent overactivation of the $5-\mathrm{HT}_{2 \mathrm{~A}} \mathrm{R}$. At P0, none of the six stained PhMns displayed the classical Tg8 multipolar dendritic tree, but all showed a bipolar tree (Fig. 7B). They still exhibited, however, an extensive dendritic tree, a similar number of distal dendrites, and a similar rate of occurrence of the dendritic spines typical of Tg8 PhMns (Fig. 7C,D). Only the rate of occurrence of the varicosities was significantly lower than in the control Tg8 (Fig. 7E). In neonates born from two pregnant Tg8 dams treated with saline, the morphology of the biocytin- 
labeled PhMns $(n=2)$ was similar to that of the control Tg8 PhMns.

\section{DISCUSSION}

To establish whether 5-HT plays a role in respiratory network maturation, comparisons were made between the respiratory activity of control $\mathrm{C} 3 \mathrm{H}$ and MAOA-deficient Tg8 neonates characterized by prenatal 5-HT excess. At birth, three main anomalies were noted in the Tg8 respiratory network: its inability to develop a stable rhythm, a defective 5-HT modulation, and an abnormal PhMn morphology. In Tg8 neonates, MAOA deficiency affects both the noradrenaline and 5-HT levels, but the increase in the noradrenaline levels is very weak compared with the 5-HT excess (Cases et al., 1995). Although the possible involvement of noradrenaline cannot be completely ruled out, it therefore seems likely that the maturational abnormalities observed here originated mainly from 5-HT excess, because prenatal treatments affecting 5-HT function and $5-\mathrm{HT}_{2 \mathrm{~A}} \mathrm{R}$ activity affected the occurrence of these abnormalities.

\section{Variability of respiratory activity and abnormal wiring of respiratory network in Tg8 neonates}

In vitro, the rat respiratory network begins at E15-E16 to generate a rhythmic activity that is very variable at first but stabilizes with age. This stabilization occurred in wild $\mathrm{C} 3 \mathrm{H}$ neonates, but in mutant Tg8 neonates, both the rhythm and amplitude of the respiratory activity are abnormally variable. The inability of the $\operatorname{Tg} 8$ centers to develop a stable activity several days after birth is likely to result from $5-\mathrm{HT}_{2 \mathrm{~A}} \mathrm{R}$ overactivation by 5 -HT excess during the prenatal period; prenatal treatment of $\mathrm{Tg} 8$ fetuses with either PCPA or 5- $\mathrm{HT}_{2 \mathrm{~A}} \mathrm{R}$ antagonist SR46349B stabilized the respiratory activity at birth, whereas prenatal treatment of $\mathrm{C} 3 \mathrm{H}$ fetuses with $5-\mathrm{HT}_{2 \mathrm{~A}} \mathrm{R}$ agonist DOI increased the variability.

The variability observed in preparations from which the periphery has been eliminated may be attributable only to central factors (Di Pasquale et al., 1996). The Tg8 rhythm variability may therefore result from maturational deficits affecting the medullary respiratory network, via the membrane properties of some of its elements and/or the wiring between its different elements. The maturation of the PhMn membrane properties was not drastically affected in $\mathrm{Tg} 8$ mice, but more severe maturational disorders may have affected the inspiratory bursting pacemaker cells, which form the kernel of the medullary network (for review, see Hilaire and Duron, 1999). In addition, the presence of an abnormal wiring of the Tg8 medullary network cannot be ruled out, because some features suggesting abnormal wiring were observed at the cervical level. First, the fact that few respiratory interneurons were detected within the Tg8 cervical cord although these neurons have been commonly encountered in the cord of fetal and neonatal rats (Di Pasquale et al., 1996) and $\mathrm{C} 3 \mathrm{H}$ mice may have resulted from an abnormal pattern of wiring between the medullary centers and their cervical targets. Second, PhMn dendritic trees differ greatly between $\mathrm{C} 3 \mathrm{H}$ and $\mathrm{Tg} 8$ neonates. The bipolar dendritic tree of a $\mathrm{C} 3 \mathrm{H} \mathrm{PhMn}$ extends mostly in the two directions in which the axons of its central drivers run (Monteau and Hilaire, 1991, their Fig. 13). The Tg8 PhMn dendrites extend in all directions, which suggests that either the axons of their medullary drivers are not in the right place or the Tg8 PhMns receive other inputs that $\mathrm{C} 3 \mathrm{H} \mathrm{PhMns}$ do not receive. Moreover, the fact that dendritic spines known to establish synaptic contacts (Saito et al., 1992; Dailey et al., 1994) show a greater density again argues for the existence of an abnormally large number of syn- aptic inputs to the Tg8 PhMns. These arguments are all indirect ones, however, and it is not yet possible to draw any definite conclusions. Whether Tg8 rhythm variability reflects a transient or permanent dysfunction of the $\operatorname{Tg} 8$ respiratory network is another open question. The mouse respiratory network is thought to be fully mature by P15-P21 (Hilaire and Duron, 1999), but the respiratory network cannot be studied at this age using the present in vitro approach.

\section{Abnormal regulation of respiratory activity by 5-HT and its receptors in Tg8 neonates}

In neonatal mice, endogenous 5-HT exerts a facilitatory modulation on the respiratory rhythm generator via medullary $5-\mathrm{HT}_{1 \mathrm{~A}} \mathrm{R}$ (Hilaire et al., 1997b). This modulation exists in $\mathrm{C} 3 \mathrm{H}$ neonates but is lacking in Tg8. The absence of 5-HT facilitatory effects in Tg8 may have resulted from the reduced expression of $5-\mathrm{HT}_{1 \mathrm{~A}} \mathrm{R}$ in the Tg8 medulla (binding data), probably attributable to 5-HT excess. This idea agrees with the finding that the 5-HT facilitatory effects were restored in Tg8 pups after 5-HT level normalization by PCPA prenatal and postnatal treatments.

At the cervical level, a dense 5-HT innervation from the raphe nuclei establishes synaptic contacts with the PhMns (Holtman et al., 1990; Pilowsky et al., 1990; Ellenberger et al., 1992), and activation of $5-\mathrm{HT}_{2 \mathrm{~A}} \mathrm{R}$ induces a tonic discharge in OF1 mouse pups (Hilaire et al., 1997b), as well as in both $\mathrm{C} 3 \mathrm{H}$ and $\mathrm{Tg} 8$ pups.

Activating cervical presynaptic $5-\mathrm{HT}_{1 \mathrm{~B}} \mathrm{R}$ depresses the amplitude of the integrated inspiratory PhMn bursts (Lindsay and Feldman, 1993; Di Pasquale et al., 1997; Hilaire et al., 1997b). This depressive effect of 5-HT is present in $\mathrm{C} 3 \mathrm{H}$ but lacking in Tg8 neonates.

The absence of both $5-\mathrm{HT}_{1 \mathrm{~A}} \mathrm{R}$ facilitatory effects on the rhythm generator and $5-\mathrm{HT}_{1 \mathrm{~B}} \mathrm{R}$ depressive effects on the burst amplitude in $\operatorname{Tg} 8$ mice contrasts with the persistence of the $5-\mathrm{HT}_{2 \mathrm{~A}} \mathrm{R}$-mediated tonic discharge. This apparent discrepancy may be attributable to the fact that $5-\mathrm{HT}_{1} \mathrm{R}$ and $5-\mathrm{HT}_{2} \mathrm{R}$ react in different ways to the 5-HT excess. Prenatal treatment with 5-HT agents may abolish $5-\mathrm{HT}_{1} \mathrm{R}$ but not $5-\mathrm{HT}_{2 \mathrm{~A}} \mathrm{R}$ responses (Shemer et al., 1991), although desensitization or downregulation of 5- $\mathrm{HT}_{2 \mathrm{~A}} \mathrm{R}$ may occur after agonist activation (McKenna et al., 1989; Ivins and Molinoff, 1991; Roth et al., 1995), particularly in adult Tg8 mice (Shih et al., 1999).

\section{Role of $5-\mathrm{HT}_{2 \mathrm{~A}}$ receptors in some effects of 5-HT excess}

The $5-\mathrm{HT}_{2 \mathrm{~A}} \mathrm{R}$ subtype is a good candidate for mediating the effects of 5-HT excess on the PhMn, because these receptors are present on their membrane (Morin et al., 1991b; Ellenberger et al., 1992; Lindsay and Feldman, 1993). In addition, various treatments affecting the $5-\mathrm{HT}_{2 \mathrm{~A}} \mathrm{R}$ induced $\mathrm{PhMn}$ morphological changes in both strains.

Short postnatal application of 5-HT to $\mathrm{C} 3 \mathrm{H}$ preparations occasionally induced the development of one to two primary dendrites in unexpected directions, and this effect was prevented by $5-\mathrm{HT}_{2 \mathrm{~A}} \mathrm{R}$ antagonist treatment. It seems quite remarkable that such a brief 5-HT application can induce dendritic outgrowth within 2-3 hr. On the one hand, this result should be treated with caution because of the smallness of the sample size and the shortness of the latency. On the other hand, dorsal horn neurons may undergo dendritic reshaping a few minutes after intense activation of substance $P$ receptors (Mantyh et al., 1995). In addition, morphological changes in the adult rat phrenic nucleus have been reported to develop within $2 \mathrm{hr}$ of cervical hemisection 
(Sperry and Goshgarian, 1993), and 5-HT may be involved in these changes (Hadley et al., 1999; Zhou and Goshgarian, 1999). Last, the effects of short 5-HT applications are completely in agreement with those observed in fetuses after applying longterm treatments to the dams. Long-term DOI activation of the $5-\mathrm{HT}_{2 \mathrm{~A}} \mathrm{R}$ in fetuses increased the total dendritic extent and induced multiple branching of distal dendrites in neonates. Conversely, preventing the $5-\mathrm{HT}_{2 \mathrm{~A}} \mathrm{R}$ activation in $\mathrm{Tg} 8$ fetuses with the antagonist SR46349B affected the overall pattern of the dendritic tree, leading to $\mathrm{Tg} 8 \mathrm{PhMns}$ with large-sized arborizations, resembling $\mathrm{C} 3 \mathrm{H} \mathrm{PhMns}$. These results strongly suggest that overactivation of $5-\mathrm{HT}_{2 \mathrm{~A}} \mathrm{R}$ affects the shaping of the PhMn dendritic tree.

The number of dendritic spines in $\mathrm{C} 3 \mathrm{H}$ PhMns was smaller than in Tg8 PhMns but increased in response to both short postnatal (5-HT) and long prenatal (DOI) treatments activating the $5-\mathrm{HT}_{2 \mathrm{~A}} \mathrm{R}$. In $\mathrm{Tg} 8$ fetuses, however, prenatal treatment with $5-\mathrm{HT}_{2 \mathrm{~A}} \mathrm{R}$ antagonist did not decrease the number of spines at birth. This may reflect 5-HT neurotrophic effects mediated via non-5- $\mathrm{HT}_{2 \mathrm{~A}} \mathrm{R}$.

The numerous varicosities formed by $\mathrm{PhMn}$ dendrites in Tg8 neonates resemble the swollen varicosities characteristic of 5-HT neurons. They may result from the 5-HT uptake and storage, because maturing neurons in Tg8 mice may transiently express the 5-HT transporter (Lebrand et al., 1996; Cases et al., 1998). These varicosities also closely resemble the histological profiles of internalized receptors (Mantyh et al., 1995) and may result from $5-\mathrm{HT}_{2 \mathrm{~A}} \mathrm{R}$ internalization in response to their overactivation by excess 5-HT. Rapid agonist-induced internalization of 5-HT ${ }_{2 \mathrm{~A}} \mathrm{R}$ has been reported to occur in a clonal cell line, which was blocked by $5-\mathrm{HT}_{2 \mathrm{~A}} \mathrm{R}$ antagonist (Berry et al., 1996). These data are in line with the reduced number of varicosities present in Tg8 PhMns at birth after prenatal $5-\mathrm{HT}_{2 \mathrm{~A}} \mathrm{R}$ antagonist treatment and the increase in their number that occurs in $\mathrm{C} 3 \mathrm{H}$ neonates after prenatal agonist treatment.

5-HT is involved in maturational processes, because it modulates cell division and differentiation, growth, and synaptogenesis (Lauder, 1993). High 5-HT levels affect the maturation of the thalamocortical (Cases et al., 1996) and retinal (Mooney et al., 1998) projections, the number of neurites present in hippocampal cells (Chubakov et al., 1986), the pattern of dendritic branching, and the number of spines occurring in dentate granule cells (Yan et al., 1997a,b). 5-HT ${ }_{1 \mathrm{~A}} \mathrm{R}$ are thought to be responsible for these cellular changes (Sikich et al., 1990; Yan et al., 1997a,b). Our results suggest that $5-\mathrm{HT}_{2 \mathrm{~A}} \mathrm{R}$ contribute to shaping the $\mathrm{PhMn}$ morphology, but other receptor types might also be involved. The existence of multiple modes of control (Levitt et al., 1997) would explain why prenatal treatment with $5-\mathrm{HT}_{2 \mathrm{~A}} \mathrm{R}$ antagonist restored a bipolar dendritic tree in Tg8 PhMns without affecting either the total dendritic length or the number of dendritic spines. Depending on the cell type (interneuron vs motoneuron), the function of the structure (hippocampus vs ventral horn of the spinal cord), and the types and densities of the receptors locally expressed (low 5- $\mathrm{HT}_{1 \mathrm{~A}} \mathrm{R}$ density in the cervical ventral horn) (Fig. $3 A$ ), different mechanisms might be involved in modulating the morphology of maturing cells.

In conclusion, the present results suggest that 5-HT actually plays an important role in respiratory network maturation. Genetic 5-HT excess in Tg8 neonates and PCPA-induced 5-HT depletion in $\mathrm{C} 3 \mathrm{H}$ neonates both affect the ability of the respiratory centers to develop a stable respiratory activity at birth. Disturbances affecting 5-HT metabolism during pregnancy might therefore have deleterious effects on the maturation of the respiratory center, resulting in respiratory dysfunction at birth. The fetal 5-HT metabolism can be disturbed by numerous factors, such as stress-inducing situations (Peters, 1989), food restrictions (Hernandez et al., 1989), antidepressive drugs, etc. It is noteworthy that defective cardiorespiratory and sleep control, which are both functions modulated by 5-HT, might partly explain sudden infant death syndrome, the victims of which have been found to show abnormally high tryptophan and 5-HIAA CSF levels (Caroff et al., 1992; Cann-Moisan et al., 1999).

\section{REFERENCES}

Berry S, Shah M, Khan N, Roth B (1996) Rapid agonist-induced internalization of the 5-hydroxytryptamine $2 \mathrm{~A}$ receptor occurs via the endosomal pathway in vitro. Mol Pharmacol 50:306-313.

Bianchi A, Denavit-Saubie M, Champagnat J (1995) Central control of breathing in mammals: neuronal circuitry, membrane properties, and neurotransmitters. Physiol Rev 75:1-45.

Boulenguez P, Chauveau J, Segu L, Morel A, Lanoir J, Delaage M (1991) A new 5-hydroxy-indole derivative with preferential affinity for 5- $\mathrm{HT}_{1 \mathrm{~B}}$ binding sites. Eur J Pharmacol 194:91-98.

Cann-Moisan C, Girin E, Giroux J, Le Bras P, Caroff J (1999) Changes in cerebrospinal fluid monoamine metabolites, tryptophan, and aminobutyric acid during the 1st year of life in normal infants. Biol Neonate 75:152-159.

Caroff J, Girin E, Alix D, Cann-Moisan C, Sizun J, Barthelemy L (1992) Neurotransmission et mort subite du nourrisson: étude du liquide céphalorachidien. CR Acad Sci III 314:451-454.

Cases O, Seif I, Grimsby J, Gaspar P, Chen K, Pournin S, Müller U, Aguet M, Babinet C, Shih JC, De Maeyer E (1995) Aggressive behavior and altered amounts of brain serotonin and norepinephrine in mice lacking MAOA. Science 268:1763-1766.

Cases O, Vitalis T, Seif I, De Maeyer E, Sotelo C, Gaspar P (1996) Lack of barrels in the somatosensory cortex of monoamine oxidase A-deficient mice: role of a serotonin excess during the critical period. Neuron 16:297-307.

Cases O, Lebrand C, Giros B, Vitalis T, De Maeyer E, Caron M, Price D, Gaspar P, Seif I (1998) Plasma membrane transporters of serotonin, dopamine, and norepinephrine mediate serotonin accumulation in atypical locations in the developing brain of monoamine oxidase A knock-outs. J Neurosci 18:6914-6927.

Chubakov A, Tsyganova V, Sarkisova E (1986) The stimulating influence of the raphe nuclei on the morphofunctional development of the hippocampus during their combined cultivation. Neurosci Behav Physiol 23:271-276.

Dailey M, Buchanan J, Bergles D, Smith S (1994) Mossy fiber growth and synaptogenesis in rat hippocampal slices in vitro. J Neurosci 14:1060-1078.

Di Pasquale E, Monteau R, Hilaire G (1992) In vitro study of central respiratory-like activity of the fetal rat. Exp Brain Res 89:459-464.

Di Pasquale E, Monteau R, Hilaire G (1994a) Endogenous serotonin modulates the fetal respiratory rhythm: an in vitro study in the rat. Dev Brain Res 80:222-232.

Di Pasquale E, Monteau R, Hilaire G (1994b) Involvement of the rostral ventro-lateral medulla in respiratory rhythm genesis during the perinatal period: an in vitro study in newborn and fetal rats. Dev Brain Res 78:243-252.

Di Pasquale E, Tell F, Monteau R, Hilaire G (1996) Perinatal developmental changes in respiratory activity of medullary and spinal neurons: an in vitro study on fetal and newborn rats. Dev Brain Res 91:121-130.

Di Pasquale E, Lindsay A, Feldman J, Monteau R, Hilaire G (1997) Serotonergic inhibition of phrenic motoneuron activity: an in vitro study in neonatal rat. Neurosci Lett 230:29-32.

Ellenberger H, Vera P, Feldman J, Holets V (1992) Multiple putative neuromessenger inputs to phrenic motoneurons in rat. J Chem Neuroanat 5:375-382.

Hadley S, Walker P, Goshgarian H (1999) Effects of serotonin synthesis inhibitor p-CPA on the expression of the crossed phrenic phenomenon 4 h following C2 spinal cord hemisection. Exp Neurol 160:479-488.

Hamon M, Gozlan H (1993) Les récepteurs centraux de la sérotonine. Médecine Sciences 9:21-30.

Hernandez J, Manjarrez G, Chagoya G (1989) Newborn humans and 
rats malnourished in utero: free plasma 1-tryptophan, neutral amino acids and brain serotonin synthesis. Brain Res 488:1-13.

Hilaire G, Duron B (1999) Maturation of the mammalian respiratory system. Physiol Rev 79:325-360.

Hilaire G, Monteau R (1997) Brainstem and spinal control of respiratory muscles during breathing. In: Neural control of the respiratory muscles (Miller AD, Bianchi AL, Bishop BP, eds), pp 91-105. New York: CRC.

Hilaire G, Bou C, Monteau R (1997a) Rostral ventrolateral medulla and respiratory rhythmogenesis in mice. Neurosci Lett 224:13-16.

Hilaire G, Bou C, Monteau R (1997b) Serotonergic modulation of central respiratory activity in the neonatal mouse: an in vitro study. Eur J Pharmacol 329:115-120.

Holtman J, Vascik D, Maley B (1990) Ultrastructural evidence for serotonin-immunoreactive terminals contacting phrenic motoneurons in the cat. Exp Neurol 109: 269-272.

Hoyer D, Clarke DE, Fozard JR, Hartig PR, Martin GR, Mylecharane EJ, Saxena PR, Humphrey PP (1994) International union of pharmacology classification of receptors for 5-hydroxytryptamine (serotonin). Pharmacol Rev 46:157-203.

Ivins K, Molinoff P (1991) Desensitization and down-regulation of 5- $\mathrm{HT}_{2}$ receptors in P11 cells. J Pharmacol Exp Ther 259:423-429.

Koshiya NK, Smith JC (1999) Neuronal pacemaker for breathing visualized in vitro. Nature 400:360-363.

Lajard A, Bou C, Monteau R, Hilaire G (1999) Serotonin levels are abnormally elevated in the foetus of MAOA-deficient transgenic mouse. Neurosci Lett 261:41-44.

Lauder J (1993) Neurotransmitters as growth regulatory signals: role of receptors and second messengers. Trends Neurosci 16:233-240.

Lauder J, Krebs H (1978) Serotonin as a differentiation signal in early embryogenesis. Dev Neurosci 1:15-30.

Lauder J, Towle A, Patrick P, Henderson P, Krebs H (1985) Decreased serotonin content of embryonic raphe neurons following maternal administration of $p$-chlorophenylalanine: a quantitative immunocytochemical study. Dev Brain Res 20:107-114.

Lebrand C, Cases O, Adelbrecht C, Doye A, Alvarez C, El Mestikawy S, Seif I, Gaspar P (1996) Transient uptake and storage of serotonin in developing thalamic neurons. Neuron 17:823-835.

Levitt P, Harvey J, Friedman E, Simansky K, Murphy H (1997) New evidence for neurotransmitter influences on brain development. Trends Neurosci 20:269-274.

Lindsay A, Feldman J (1993) Modulation of respiratory activity of neonatal rat phrenic motoneurons by serotonin. J Physiol (Lond) 461:213-233.

Liu Q, Feldman J, Smith J (1990) Excitatory amino acid-mediated transmission of inspiratory drive to phrenic motoneurons. J Neurophysiol 64:423-437.

Mantyh P, DeMaster E, Malhotra A, Ghilardi J, Rogers S, Mantyh C, Liu H, Basbaum A, Vigna S, Maggio J, Simone D (1995) Receptor endocytosis and dendrite reshaping in spinal neurons after somatosensory stimulation. Science 268:1629-1632.

McKenna D, Nazarali A, Himeno A, Saavedra J (1989) Chronic treatment with $(+/-)$ DOI, a psychotomimetic $5-\mathrm{HT}_{2}$ agonist, downregulates $5-\mathrm{HT}_{2}$ receptors in rat brain. Neuropsychopharmacology 2:81-87.

Monteau R, Hilaire G (1991) Spinal respiratory motoneurons. Prog Neurobiol 37:83-144.
Monteau R, Di Pasquale E, Hilaire G (1994) Further evidence that various 5-HT receptor subtypes modulate central respiratory activity: in vitro studies with SR46349B. Eur J Pharmacol 259:71-74.

Mooney R, Crnko-Hoppenjans T, Ke M, Bennett-Clarke C, Lane R, Chiaia N, Rhoades R (1998) Augmentation of serotonin in the developing superior colliculus alters the normal development of the uncrossed retinotectal projection. J Comp Neurol 393:84-92.

Morin D, Monteau R, Hilaire G (1991a) 5-Hydroxytryptamine modulates central respiratory activity in the newborn rat: an in vitro study. Eur J Pharmacol 192:89-95.

Morin D, Monteau R, Hilaire G (1991b) Serotonin and cervical respiratory motoneurons: intracellular study in the newborn rat brainstemspinal cord preparation. Exp Brain Res 84:229-232.

Peroutka S (1994) Molecular biology of serotonin (5-HT) receptors. Synapse 18:241-260.

Peters D (1989) Effects of maternal stress during different gestational periods on the serotonergic system in adult rat offspring. Pharm Biochem Behav 31:839-843.

Pilowsky P, De Castro I, Llewellyn-Smith P, Lipski P, Voss M (1990) Serotonin immunoreactive boutons made synapses with feline phrenic motoneurons. J Neurosci 10:1091-1098.

Roth B, Palvimaki E, Berry S, Khan N, Sachs N, Uluer A, Choudhary M (1995) 5-Hydroxytryptamine ${ }_{2 \mathrm{~A}}\left(5-\mathrm{HT}_{2 \mathrm{~A}}\right)$ receptor desensitization can occur without down-regulation. J Pharmacol Exp Ther 275:1638-1646.

Saito Y, Murakami F, Song W, Okawa K, Shimono K, Katsumaru H (1992) Developing corticorubral axons of the cat form synapses on filipodia dendritic protrusions. Neurosci Lett 147:81-84.

Shemer A, Azmitia E, Whitaker-Azmitia P (1991) Dose related effects of prenatal 5-methoxytryptamine (5-MT) on development of serotonin terminal density and behavior. Dev Brain Res 59:59-63.

Shih JC, Ridd MJ, Chen K, Meehan WP, Kung MP, Seif I, De Maeyer E (1999) Ketanserin and tetrabenazine abolish aggression in mice lacking monoamine oxidase A. Brain Res 835:104-112.

Sikich L, Hickok J, Todd R (1990) 5-HT 1 A receptors control neurite branching during development. Dev Brain Res 56:269-274.

Sperry M, Goshgarian H (1993) Ultrastructural changes in the rat phrenic nucleus developing within $2 \mathrm{~h}$ after cervical spinal cord hemisection. Exp Neurol 120:233-244.

Vogt M (1982) Some functional aspects of central serotonergic neurons. In: Biology of serotonergic transmission (Osborne N, ed), pp 299-315. New York: Wiley.

Whitaker-Azmitia PM (1991) Role of serotonin and other neurotransmitter receptors in brain development: basis for developmental pharmacology. Pharmacol Rev 34:553-561.

Yan W, Wilson C, Haring J (1997a) Effects of neonatal serotonin depletion on the development of rat dentate granule cells. Dev Brain Res 98:177-184.

Yan W, Wilson C, Haring $\mathrm{J}$ (1997b) $5-\mathrm{HT}_{1 \mathrm{~A}}$ receptors mediate the neurotrophic effect of serotonin on developing dentate granule cells. Dev Brain Res 98:185-190.

Zhou S, Goshgarian H (1999) Effects of serotonin on crossed phrenic nerved activity in cervical spinal cord hemisected rats. Exp Neurol 160:446-453. 